\title{
Cellular communication promotes mammosphere growth and collective invasion through microtubule-like structures and angiogenesis
}

\author{
SHANGKE HUANG ${ }^{1 *}$, NA YUAN $^{2 *}$, GUANYING WANG $^{1}$, FANG WU $^{3}$, LU FENG $^{1}$, \\ MINNA LUO ${ }^{4}$, MIAO LI $^{5}$, ANQI LUO $^{1}$, XINHAN ZHAO $^{1}$ and LINGXIAO ZHANG ${ }^{1}$ \\ Departments of ${ }^{1}$ Medical Oncology, ${ }^{2}$ Ultrasound, ${ }^{3}$ Neonatology and ${ }^{4}$ Hematology, The First Affiliated Hospital \\ of Xi'an Jiaotong University, Xi'an, Shaanxi 710061; ${ }^{5}$ Department of Medical Oncology, \\ The Fifth People's Hospital of Qinghai Province, Xining, Qinghai 810007, P.R. China
}

Received March 5, 2018; Accepted September 27, 2018

DOI: $10.3892 / o r .2018 .6778$

\begin{abstract}
Networks of nanotubes and microtubules are highly valued in cellular communication, and collective cancer movement has been revealed to be associated with cell information exchange. In the present study, cellular communication was demonstrated to participate in mammosphere growth, differentiation and collective invasion. By promoting differentiation, networks of cells and microtubule-like structures were verified. Analyses of cell cycle progression, stemness markers and gene expression indicated that mammospheres had collective characteristics of stemness and differentiation. Invasion assays revealed that networks of microtubule-like structures promoted collective invasion. Conversely, using anti-angiogenic intervention, the growth of stem-like mammospheres and cellular communication links were effectively inhibited. In vivo experiments revealed that cellular communication promoted tumor growth and metastasis through the formation of nodular fusion, cluttered microtubule-like structures and cancer stem cells, as well as vascular niches. In conclusion, the present results demonstrated that a network of cells and structures were largely present in mammosphere cellular communication in vitro and in vivo. Therefore, blocking cellular communication may prove beneficial in halting the progression of mammary tumors.
\end{abstract}

Correspondence to: Professor Xinhan Zhao or Dr Lingxiao Zhang, Department of Medical Oncology, The First Affiliated Hospital of Xi'an Jiaotong University, 277 Yanta West Road, Xi'an, Shaanxi 710061, P.R. China

E-mail: zhaoxinhanprof@163.com

E-mail: zhanglx86@sina.com

${ }^{*}$ Contributed equally

Key words: mammosphere, cancer stem cells, cellular communication, microtubule-like, collective invasion, angiogenesis

\section{Introduction}

Cancer stem cells (CSCs) are considered the source of cancer recurrence, treatment resistance and distant metastasis (1). Al-Hajj et al (2) reported that the cluster of differentiation (CD) $44^{+} \mathrm{CD} 24^{-/{ }^{\text {low }} \text { Lineage }}$ breast cancer cells are consistently considered breast CSCs (BCSCs). As research has progressed, further BCSC markers, such as aldehyde dehydrogenase 1 (3) and CD133 (4), have been identified. In clinical analysis, stemness and phenotypic markers exhibit more heterogeneity in the intra-tumor heterogeneity as partially attributing to the different CSCs and subclones of cancer cells $(5,6)$. In addition, researchers have reported that collective cancer movement promotes tumor progression through differently labeled cell populations $(7,8)$. Since asymmetrical division and multi-differentiation potency are the main features of CSCs $(9,10)$, there is reason to believe that cells have differentiated and evolved to specialize for different functions. For example, CSCs have been revealed to differentiate into endothelial cells and participate in tumor angiogenesis (11). Notably, already asymmetrically divided or differentiated cells can, in turn, maintain CSC stemness; however, this mechanism remains to be explored. A recent study confirmed that the stemness characteristic is maintained through the asymmetrical division of aged mitochondria (12).

Collective invasion has been described as a novel behavior of tumor cells in cancer metastasis $(7,8)$. However, the reasons for collective invasion remain unclear. It has been reported that collective invasion may be associated with the heterogeneity of cell populations and differences between cell markers (7). Other studies have confirmed that vascular and fibronectin-focal adhesion kinase signaling $(8,13)$, and cytokine networks (14) have evolved from the tumor microenvironment, and may participate in the collective invasion process. In the process of collective invasion, it appears that information is being exchanged and communicated among cells (8). However, to the best of our knowledge, there are no reports of intercellular structural involvement. The association between collective movement, and CSCs and vascular niches also remains poorly understood (15). 
In a recent study, Baker discussed and summarized the concept of the cell network as well as the role of networks of nanotubes and microtubules within it (16). Networks of nanotubes are considered to participate in cellular communication, allowing for the sharing and exchange of various content and information (16-18). A previous study demonstrated that the stem cell marker CD133 may be transferred between hematopoietic cells via tunneling nanotubes (19). Similar membrane microtubules have been detected in vitro and are considered to be, in part, a result of brain CSC differentiation (20). Networks of microtubules have been reported to markedly promote the malignant progression of brain tumors $(20,21)$; however, despite reports of nanotubes in vitro $(22,23)$, reports of structural networks participating in cellular communication in mammosphere growth and invasion are rare.

In the present study, cellular communication was revealed to be widely present in mammosphere growth and collective invasion, through networks of microtubule-like structures and angiogenesis in vitro and in vivo, and the mechanism was explored. The present study aimed to demonstrate a novel behavior of cellular communication in the progression of mammary tumors, and to identify the stemness and differentiation characteristics of mammospheres. In addition, the effects of anti-vascular endothelial growth factor (VEGF) treatment on the prevention of mammary tumor progression were analyzed.

\section{Materials and methods}

Animals. A total of 26 Female athymic nude mice (age, 3-5 weeks; weight, 16.1 $\pm 0.4 \mathrm{~g}$ ) were purchased from Shanghai Silaike Laboratory Animal Co., Ltd. (Shanghai, China). The experimental protocol was conducted according to the Regulations of Experimental Animal Administration issued by the Ministry of Science and Technology of the People's Republic of China. Mouse care and usage were approved by the Ethics Committee of the School of Medicine of Xi'an Jiaotong University (approval no. 0108; Xi'an, China). The mice were maintained in air-conditioned pathogen-free rooms with ad libitum access to food and water, at $25 \pm 2^{\circ} \mathrm{C}$ and $55 \%$ humidity under a controlled light-dark cycle (12-12 h).

Cells and culture. MDA-MB-231 and MCF-7 human breast cancer cell lines, and the MCF-10A human normal breast cell line, at passages 3-15 were obtained from the Cell Bank of the Chinese Academy of Sciences (Shanghai, China). MCF-10A cells were cultured in Dulbecco's modified Eagle's medium (DMEM)/F12 (Thermo Fisher Scientific, Inc., Waltham, MA, USA) supplemented with $5 \%$ horse serum (Thermo Fisher Scientific, Inc.), $10 \mu \mathrm{g} / \mathrm{ml}$ insulin (Thermo Fisher Scientific, Inc.), $100 \mathrm{ng} / \mathrm{ml}$ cholera toxin (Biomol GmbH, Hamburg, Germany) and $0.5 \mu \mathrm{g} / \mathrm{ml}$ hydrocortisone (Merck KGaA, Darmstadt, Germany). MDA-MB-231 cells were cultured in RPMI 1640 medium (Thermo Fisher Scientific, Inc.) supplemented with $10 \%$ fetal bovine serum (FBS; Thermo Fisher Scientific,Inc.), $100 \mathrm{U} / \mathrm{ml}$ penicillin and $100 \mu \mathrm{g} / \mathrm{ml}$ streptomycin (Thermo Fisher Scientific, Inc.). MCF-7 cells were cultured in DMEM (Thermo Fisher Scientific, Inc.) supplemented with $10 \%$ FBS. All cell lines were cultured at $37^{\circ} \mathrm{C}$ in an atmosphere containing $5 \% \mathrm{CO}_{2}$. Primary MDA-MB-231 or MCF-7 cells were obtained from xenograft tissues; xenografts were generated by subcutaneously implanting $1 \times 10^{6}$ MDA-MB-231 or MCF-7 cells into six athymic nude mice ( $n=3 /$ group; approval no. 0108), according to the method described by Al-Hajj et al (2). When the MDA-MB-231 or MCF-7 xenografts reached $1 \mathrm{~cm}^{3}$, the fresh tumor tissues were harvested and digested into a single cell (2) suspension in DMEM/F12 supplemented with $10 \% \mathrm{FBS}$; these cells were referred to as the primary MDA-MB-231 or MCF-7 cells, respectively. Subsequently, MDA-MB-231 or MCF-7 mammospheres, and primary MDA-MB-231 or MCF-7 mammospheres, were generated from parental MDA-MB-231/MCF-7 and primary MDA-MB-231/MCF-7 cells; for mammosphere generation, these cells were harvested and were maintained in mammosphere culture conditions (24). Specifically, all of the mammospheres were cultured in serum-free DMEM/F12 medium solution mix, supplemented with B27 (1:50, Thermo Fisher Scientific, Inc.), $20 \mathrm{ng} / \mathrm{ml}$ human epidermal growth factor (Merck KGaA) and $20 \mathrm{ng} / \mathrm{ml}$ human basic fibroblast growth factor (Merck KGaA) (24,25). Mammospheres were collected by gentle centrifugation $(1,000 \mathrm{x} \mathrm{g})$ after 7-10 days and were dissociated enzymatically [10 min in $0.05 \%$ trypsin (Thermo Fisher Scientific, Inc.)] (24). For differentiation assays, mammospheres were collected and then cultured in DMEM/F12 supplemented with 10, 5 and 1\% FBS.

Cell surface markers and cell cycle analysis. MDA-MB-231 and MCF-7 cells were washed three times with PBS and collected following trypsinization. A suspension of mammosphere cells was collected and centrifuged at 1,000 x g for 5 min after trypsinization into single cells. Subsequently, collected cells $\left(1 \times 10^{5}-1 \times 10^{6}\right)$ were resuspended in 50-100 $\mu \mathrm{l}$ PBS, after which, $5 \mu \mathrm{l}$ anti-CD44-fluorescein isothiocyanate (FITC) antibodies (cat. no. 560977; BD Biosciences, Franklin Lakes, NJ, USA) and $5 \mu \mathrm{l}$ anti-CD24-phycoerythrin (PE) antibodies (cat. no. 560991; BD Biosciences) were added in succession. Subsequently, the labeled cells were incubated at $37^{\circ} \mathrm{C}$ for $1 \mathrm{~h}$ in the dark; the same volume of isotype control antibodies [FITC-labeled/PE-labeled immunoglobulin G (IgG), cat. nos. 555742 and 555574; BD Biosciences] was added to the control group. The labeled cells were then examined by flow cytometry on a FACSCalibur flow cytometer (BD Biosciences), following two rounds of washing in cold PBS. For cell cycle analysis, all cells were harvested and fixed with $75 \%$ ethanol on ice for $24 \mathrm{~h}$. Subsequently, the cells were treated with $0.1 \%$ RNase A (Nanjing KeyGen Biotech Co., Ltd., Nanjing, China) in PBS at $37^{\circ} \mathrm{C}$ for $30 \mathrm{~min}$ and stained with $50 \mu \mathrm{g} / \mathrm{ml}$ propidium iodide (Nanjing KeyGen Biotech Co., Ltd.) at room temperature for $30 \mathrm{~min}$, after which, cell cycle analysis was conducted using a flow cytometer (FACSCalibur; BD Biosciences) and FlowJo 10.0 software (FlowJo, LLC, Ashland, OR, USA) was used for analysis. Experiments were performed in triplicate.

Statistical assessment of polymerase chain reaction (PCR) datasets. The PCR data of all cell types were analyzed using the Real-Time PCR analysis software and platform (Bio-Rad Laboratories, Inc., Hercules, CA, USA), in order to generate quantification cycle $(\mathrm{Cq})$ values for each gene. Briefly, cells were collected and total RNA was extracted using TRIzol ${ }^{\circledR}$ 
reagent (Invitrogen; Thermo Fisher Scientific, Inc.), according to the manufacturer's protocol. First-strand cDNA was synthesized from $2 \mu \mathrm{g}$ total RNA using a Reverse Transcription kit (Takara Bio, Inc., Otsu, Japan), according to the manufacturer's protocol. All primer sequences were obtained from the National Center for Biotechnology Information (https://www. ncbi.nlm.nih.gov/) and are presented in Table I. The PCR reaction mixture (Takara Bio, Inc.) contained $10 \mu \mathrm{l}$ SYBR premix EX Taq (2X), $0.8 \mu \mathrm{l}$ forward and reverse primers $(2.5 \mu \mathrm{M}), 5 \mu \mathrm{l}$

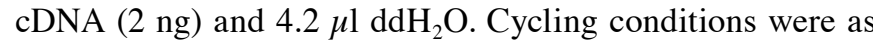
follows: Denaturation at $95^{\circ} \mathrm{C}$ for $1 \mathrm{~min}$, followed by 40 cycles of denaturation at $95^{\circ} \mathrm{C}$ for $20 \mathrm{sec}$, annealing at $60^{\circ} \mathrm{C}$ for $5 \mathrm{sec}$ and extension at $72^{\circ} \mathrm{C}$ for $30 \mathrm{sec}$, with a final $10 \mathrm{~min}$ extension at $72^{\circ} \mathrm{C}$. $\beta$-actin was used as the internal control. Normalized $\mathrm{Cq}$ values were converted to relative $\log _{10}$ or $\log _{2}$ expression values. All gene expression levels were calculated using the $2^{-\Delta \Delta \mathrm{Cq}}$ method (26).

Cell migration and invasion assays. For the migration assays, $4 \times 10^{4}$ non-trypsin-treated primary MDA-MB-231 mammosphere cells/well were seeded into the top compartment of a 24-well plate on $8-\mu \mathrm{m}$ transwell filters (EMD Millipore, Billerica, MA, USA) in $200 \mu \mathrm{l}$ pure DMEM/F12 medium. In the lower chamber, $600 \mu \mathrm{l}$ DMEM/F12 medium supplemented with $20 \%$ FBS was added. Subsequently, cells were incubated for $24 \mathrm{~h}$ at $37^{\circ} \mathrm{C}$ in $5 \% \mathrm{CO}_{2}$, and non-migratory cells were removed using a cotton swab. Cells that adhered to the underside of the membrane were fixed with $4 \%$ paraformaldehyde for $30 \mathrm{~min}$ at room temperature and stained with $0.1 \%$ crystal violet solution for $20 \mathrm{~min}$ at room temperature in the dark. For the invasion assay, the bottom of the $25 \mathrm{~cm}^{2}$ suspension culture bottle (Corning Inc., Corning, NY, USA), which contained the primary MDA-MB-231 mammospheres in serum-free DMEM/F12 medium solution supplemented with B27 (1:50, Thermo Fisher Scientific, Inc.), $20 \mathrm{ng} / \mathrm{ml}$ human epidermal growth factor (Merck KGaA) and $20 \mathrm{ng} / \mathrm{ml}$ human basic fibroblast growth factor (Merck KGaA), was coated with $0.75 \mathrm{mg} / \mathrm{ml}$ Matrigel (BD Biosciences) and cells were cultured at $37^{\circ} \mathrm{C}$ in $5 \% \mathrm{CO}_{2}$.

Western blot analysis. Primary MDA-MB-231 mammosphere cells were treated with $5 \mu \mathrm{g} / \mathrm{ml}$ bevacizumab (Shanghai Roche Pharmaceuticals Co., Ltd., Shanghai, China) (27) for $24 \mathrm{~h}$ at $37^{\circ} \mathrm{C}$ in $5 \% \mathrm{CO}_{2}$. Harvested mammospheres were lysed using radioimmunoprecipitation assay lysis buffer (Merck $\mathrm{KGaA}$ ) containing $2 \mathrm{mg} / \mathrm{ml}$ protease inhibitors for $30 \mathrm{~min}$. The lysates were then centrifuged at $12,000 \mathrm{x} \mathrm{g}$ for $20 \mathrm{~min}$ at $4^{\circ} \mathrm{C}$, followed by boiling in loading buffer for $5 \mathrm{~min}$. Total protein concentrations were determined using a Bio-Rad protein assay kit (Bio-Rad Laboratories, Inc.). Following protein extraction, equal amounts of total cellular protein $(150 \mu \mathrm{g})$ were separated by $10 \%$ SDS-PAGE and were transferred onto polyvinylidene difluoride membranes (EMD Millipore). After blocking with 5\% non-fat dry milk dissolved in Tris-buffered saline containing $0.1 \%$ Tween-20 (Bio-Rad Laboratories, Inc.) for $1 \mathrm{~h}$ at room temperature, membranes were incubated overnight at $4^{\circ} \mathrm{C}$ with the indicated antibodies. Subsequently, the immunoblots were probed with horseradish peroxidase (HRP)-conjugated secondary anti-

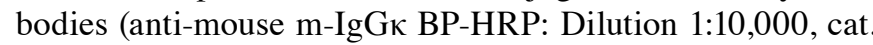

no. sc-516102; mouse anti-rabbit IgG-HRP: Dilution 1:5,000, cat. no. sc-2357; both Santa Cruz Biotechnology, Inc., Dallas, TX, USA) for $2 \mathrm{~h}$ at room temperature and were visualized using enhanced chemiluminescence (GE Healthcare, Chicago, IL, USA). Images were captured using a ChemiDoc ${ }^{\mathrm{TM}} \mathrm{MP}$ system (Bio-Rad Laboratories, Inc.). $\beta$-actin was used as a control. Signals were semi-quantified using Image-Pro Plus 6.0 software (Media Cybernetics, Inc. Rockville, MD, USA). The primary antibodies used in the present study were as follows: Mouse monoclonal anti-VEGF (dilution 1:500; cat. no. ab1316; Abcam, Cambridge, UK), mouse monoclonal anti-CD31 (dilution 1:1,000; cat. no. ab24590; Abcam), rabbit polyclonal anti-CD133 (dilution 1:1,000; cat. no. ab19898; Abcam), rabbit polyclonal anti-matrix metalloproteinase 1 (MMP1; dilution 1:1,000; cat. no. 10371-2-AP; Wuhan Sanying Biotechnology, Wuhan, China) and mouse monoclonal anti- $\beta$-actin (dilution 1:1,000; cat. no. sc-47778; Santa Cruz Biotechnology, Inc.).

CSC formation and blocking assay. Anti-CD44-FITC and anti-CD24-PE (cat. nos. 560977 and 560991; BD Biosciences) were used to sort $\mathrm{CD} 44^{+} \mathrm{CD} 24$ - cells ( $>90 \%$ purity) from the trypsinized primary MDA-MB-231 mammospheres using BD FACSMelody ${ }^{\mathrm{TM}}$ (BD Biosciences). Subsequently, equal amounts of cells $\left(\sim 1 \times 10^{3}\right)$ were allocated to each group and were introduced to the in vitro mammosphere culture system, in which cells were cultured in suspension in 24-well plates (Corning, Inc.) with serum-free DMEM/F12 medium, supplemented with B27 (1:50; Thermo Fisher Scientific, Inc.), $20 \mathrm{ng} / \mathrm{ml}$ human epidermal growth factor (Merck KGaA) and $20 \mathrm{ng} / \mathrm{ml}$ human basic fibroblast growth factor (Merck KGaA). After 8 days, the number of mammospheres was counted and bevacizumab $(5 \mu \mathrm{g} / \mathrm{ml})$ (27) was added, and after 2 weeks, the number of mammospheres was recounted, and $5 \mu \mathrm{g} / \mathrm{ml}$ bevacizumab was added at 22 days. No interventions were made to the control group. Each experimental group had three replicates.

Orthotopic xenograft tumor model. A total of 20 athymic nude mice were randomly divided into two groups ( $n=10 /$ group); approximately $1 \times 10^{6}$ MDA-MB-231 cells were subcutaneously implanted into the mice of the first group, and $\sim 1 \times 10^{4}$ MDA-MB-231 mammospheres were subcutaneously implanted into the mice of the second group. The growth of implanted xenograft tumors was monitored every 3-4 days, and the tumor volumes were calculated according to the following formula: Volume $=\left(\right.$ length $\mathrm{x}$ width $\left.{ }^{2}\right) / 2$. After 1 month, mice were sacrificed by cervical dislocation under anesthesia. For immunohistochemistry and hematoxylin and eosin staining (H\&E), the tumor tissues were harvested, fixed in $4 \%$ paraformaldehyde solution for $12 \mathrm{~h}$ at $4^{\circ} \mathrm{C}$ and embedded in paraffin. Sections $(4 \mu \mathrm{m})$ were continuously sliced and stained with H\&E (AR1180; Wuhan Boster Biological Technology, Ltd., Wuhan, China), according to the manufacturer's protocol.

Immunohistochemical staining and evaluation. The protein expression in the xenograft tissues was characterized by immunohistochemistry. Briefly, the tissue sections $(4 \mu \mathrm{m})$ were dewaxed, rehydrated and treated with $3 \% \mathrm{H}_{2} \mathrm{O}_{2}$ in methanol for $10 \mathrm{~min}$ at room temperature to inactivate endogenous peroxidase activity, followed by antigen retrieval in $0.01 \mathrm{~mol} / \mathrm{l}$ citrate 
Table I. Primers for quantitative polymerase chain reaction.

\begin{tabular}{ll} 
Gene name & \multicolumn{1}{c}{ Primer sequences } \\
\hline Human CD44 & F: 5'-TTACAGCCTCATCAGCAGAGCAC-3' \\
Human c-Myc & R: 5'-CAATGGTGTGACGCAGGGAT-3' \\
Human SOX2 & F: 5'-CAAGAGGCGAACACACAACG-3' \\
& R: 5'-GTCGTTTCCGCAACAAGTCC-3' \\
Human NANOG & F: 5'-AACCAGCGCATGGACAGTTA-3' \\
& R: 5'-CGAGCTGGTCATGGAGTTGT-3' \\
Human POU5F1 & F: 5'-CAATGGTGTGACGCAGGGAT-3' \\
Human VEGF & R: 5'-TGCACCAGGTCTGAGTGTTC-3' \\
Human MMP1 & F: 5'-GCCGCTGGCTTATAGAAGGT-3' \\
& R: 5'-CTCTCCCCAGCTTGCTTTGA-3' \\
Human $\beta$-actin & F: 5'-AACTTTCTGCTGTCTTGG-3' \\
& R: 5'-ACTTCGTGATGATTCTGC-3' \\
& F: 5'-AGAAAGAAGACAAAGGCAAGTTGA-3' \\
& R: 5'-CCACATCTGGGCTGCTTCAT-3' \\
& F: 5'-AGCGAGCATCCCCCAAAGTT-3' \\
\end{tabular}

CD44, cluster of differentiation 44; MMP1, matrix metalloproteinase 1; NANOG, Nanog homeobox; POU5F1, POU class 5 homeobox 1; SOX2, SRY-box 2; VEGF, vascular endothelial growth factor; F, forward; R, reverse.

buffer (pH 6.0) in a microwave for 15 min. After blocking with $10 \%$ normal goat serum (Thermo Fisher Scientific, Inc.) in PBS at room temperature for $30 \mathrm{~min}$, the sections were incubated with mouse monoclonal anti-VEGF (dilution 1:100; cat. no. ab1316; Abcam), mouse monoclonal anti-proliferating cell nuclear antigen (PCNA; dilution 1:100; cat. no. 60097-1-Ig; Wuhan Sanying Biotechnology), rabbit polyclonal anti-MMP1 (dilution 1:100; cat. no. 10371-2-AP; Wuhan Sanying Biotechnology) and mouse monoclonal anti-CD31 (dilution 1:50; cat. no. ab24590; Abcam) antibodies overnight at $4{ }^{\circ} \mathrm{C}$. Rabbit IgG (dilution 1:100; cat. no. ab172730; Abcam) served as the negative control. After washing with PBS, the bound antibodies were detected using HRP-anti-rabbit/anti-mouse IgG (mouse anti-rabbit IgG-HRP: Dilution 1:1,000, cat. no. sc-2357; anti-mouse m-IgGк BP-HRP; Dilution 1:1,000, cat. no. sc-516102; both Santa Cruz Biotechnology, Inc.) for $15 \mathrm{~min}$ at $37^{\circ} \mathrm{C}$. The sections were treated using the SABC kit (Wuhan Boster Biological Technology, Ltd.), according to the manufacturer's protocol. Sections were visualized using freshly prepared $0.1 \%$ DAB (Agilent Technologies, Inc., Santa Clara, CA, USA) for $5 \mathrm{~min}$ at room temperature, and were then counterstained with $5 \%$ hematoxylin for $30 \mathrm{sec}$ at room temperature to stain the nuclei, after which, they were dehydrated in a graded series of alcohol solutions. Two investigators independently evaluated expression levels in a blinded manner. Semi-quantitative analysis of staining distribution was scored as,,-+++ and +++ according to the percentage of immunoreactive cells. Specifically, '-' indicated complete absence of staining or weak staining in $<1 \%$ of the tumor cells, ' + ' indicated focal staining in $1-10 \%$ of tumor cells, ' ++ ' indicated positive staining in $11-50 \%$ of tumor cells, and ' +++ ' indicated positive staining in $>50 \%$ of tumor cells. When $>10 \%$ of tumor cells exhibited immunoreactivity, the sample was defined as immunopositive. The membranous or cytoplasmic expression of VEGF and MMP1, and the nuclear expression of PCNA were considered positive events using a light microscope (Olympus BX51; Olympus Corporation, Tokyo, Japan).

Microvessel density (MVD) assay. The MVD of mouse sections was determined by staining with anti-CD31 (dilution 1:50; cat. no. ab24590; Abcam); staining was evaluated using a light microscope (Olympus BX51; Olympus Corporation), according to the method recommended by Weidner et al (28). Initially, microvascular staining was observed at a magnification of x100. Subsequently, three 'hot spots' were selected in the regions of highest vascular density. Each brown immunostained endothelial cell or endothelial cell cluster, which was clearly separate from the adjacent micovessels and stromal structures, was counted as a single microvessel. To define MVD, the mean number of microvessels in each field was counted in each of the paraffin-embedded mouse sections (n=10/group).

Immunohistochemical fluorescence staining. Frozen sections of xenograft tumors were washed three times with PBS and were then dried on ice. The cell membranes were penetrated using $1 \%$ Triton $\mathrm{X}-100$ for $10 \mathrm{~min}$ and the cells were then washed a further three times with PBS for $5 \mathrm{~min}$. Following incubation with 5\% bovine serum albumin [Serana (WA) Pty Ltd., Bunbury, WA, Australia] for $30 \mathrm{~min}$ at room temperature, rabbit polyclonal anti-CD133 (dilution 1:100; cat. no. ab19898; Abcam) and mouse monoclonal anti-CD31 antibodies (dilution 1:50; cat. no. ab24590; Abcam) were added at $4^{\circ} \mathrm{C}$ overnight. Subsequently, sections were incubated with the relative FITC-labeled anti-rabbit/PE-labeled anti-mouse IgG antibodies (dilution 1:1,000; cat. no. ab6717/dilution 1:200; cat. no. ab5881; 
Abcam) at $37^{\circ} \mathrm{C}$ for $1 \mathrm{~h}$ in the dark. After washing with PBS, nuclear counterstaining of the sections was performed using $1 \mu \mathrm{g} / \mathrm{ml}$ DAPI (Santa Cruz Biotechnology, Inc.) for $10 \mathrm{~min}$ at room temperature in the dark. After washing twice with PBS, the sections were treated with anti-quenchable sealing oil, and were observed and analyzed using a fluorescence microscope (ECLIPSE Ti; Nikon Corporation, Tokyo, Japan).

Statistical analysis. All statistical analyses were performed using SPSS 18.0 software (SPSS, Inc., Chicago, IL, USA). Representative images are presented or data are expressed as the means \pm standard deviation/standard error of the mean $(n \geq 3)$. Differences among groups were determined using one-way analysis of variance (ANOVA) or two-tailed Student's t-test. Multiple group comparisons were performed by one-way ANOVA, followed by a Tukey's multiple comparison test. Qualitative data were compared using the $\chi^{2}$ test or Fisher's exact test. All statistical comparisons were two-sided. $\mathrm{P}<0.05$ was considered to indicate a statistically significant difference.

\section{Results}

Cellular communication exists widely in mammosphere fusion and differentiation. The primary MDA-MB-231 cells were harvested and cultured in the in vitro mammosphere culture systems. Initially, the primary mammospheres continued to attract and swallow smaller cell spheres (Fig. 1Aa-c). Subsequently, cellular-like protrusions appeared and the irregular mammosphere morphology was maintained (Fig. 1B). In addition, cell fusion occurred when two medium-sized mammospheres came into contact (Fig. 1C). When two larger mammospheres moved alongside each other, they communicated with each other through cellular-like protrusions (Fig. 1D) (20,29). Some microtubule-like contacts were revealed to participate in this mammosphere-to-mammosphere communication (Fig. 1Ea and b). Notably, cell fusion also occurred, albeit $>1$ week after these connections were formed between the large mammospheres (Fig. 1F).

By adding different concentrations of serum-containing medium (10,5 and 1\%), it was demonstrated that the higher the concentration, the faster the cell fusion was promoted (data not shown). Notably, $1 \%$ serum-containing medium made it easier to observe the slow alterations in cellular communication. The results demonstrated that the mammospheres differentiated into linear leaf-shaped cells with cord-like arrangements from their periphery (Fig. 1G and H). Microtubule-like structures were differentiated and grew in or around the mammospheres (Fig. 1H-J). Combined, these results indicated that cellular communication may be present in mammospheres during the entire process of dynamic formation and differentiation in vitro.

Networks of cells and microtubules are differentiated among mammospheres. In order to further clarify the footprints of cellular communication, mammospheres were continuously cultured in $1 \%$ serum-containing medium. The results demonstrated that microtubule-like structures and fibrous cellular-like cables could further divide into various branches and were widely distributed in the cellular space (Fig. 2Aa-c) Varieties of sphere cells were connected and surrounded with these network links (Fig. 2B). Networks of cells were

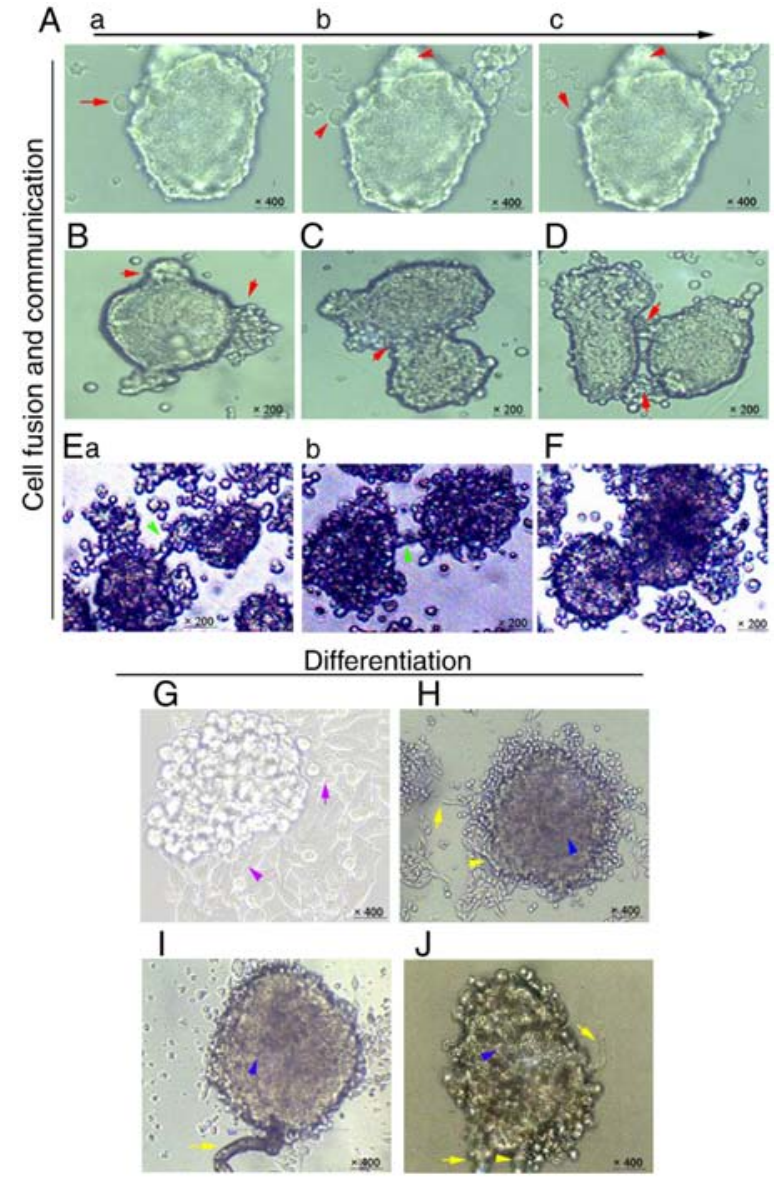

Figure 1. Cellular communication in mammosphere fusion and differentiation. (Aa-c) Initial primary mammospheres (red arrows show the dynamic positional changes of the moving cells and spheres into mammospheres; magnification, $\mathrm{x} 400$ ). (B) Cell protrusions on irregular mammospheres (red arrows; magnification, x200). (C) Cell fusion of two medium-sized mammospheres (magnification, $\mathrm{x} 200$ ). (D) When two large mammospheres came into contact communication was observed (red arrows represent cell-to-cell protrusions; magnification, x200). (Ea and b) Microtubule-like contacts among mammospheres (crystal violet staining, green arrows; magnification, $\mathrm{x} 200$ ). (F) Cell fusion of large-sized mammospheres (crystal violet staining; magnification, $\mathrm{x} 200$ ). (G) Mammospheres began to differentiate from their periphery (purple arrows indicate cord-like arrangement cells; magnification, $\mathrm{x} 400$ ). (H-J) Microtubule-like structures were differentiated in the periphery (yellow arrows) and within the mammospheres (blue arrows; magnification, x400).

even re-differentiated and transported along these links (Fig. 2Ca and b). As expected, nanotube-like structures on membranes were also observed in cell-to-cell and mammosphere-to-mammosphere communications (Fig. 2Da and b). Some cord-like connective structures were differentiated and made up by deformed cell clusters (Fig. 2E). Furthermore, a large number of structures, including vascular epithelium and vasculogenic mimics, were found to emerge from a change in cell morphology, forming another communication channel network (Fig. 2F and G). Similar networks of cells were also observed in these cell channels (Fig. 2Gc). Combined, these results indicated that various communication networks may be differentiated among mammospheres and cells in vitro.

High percentage of $C D 44^{+} / C D 24^{+}$or $C D 44^{+} / C D 24^{-}$cells is present in mammospheres. CSC markers were compared between mammospheres and their parental cells. The results 


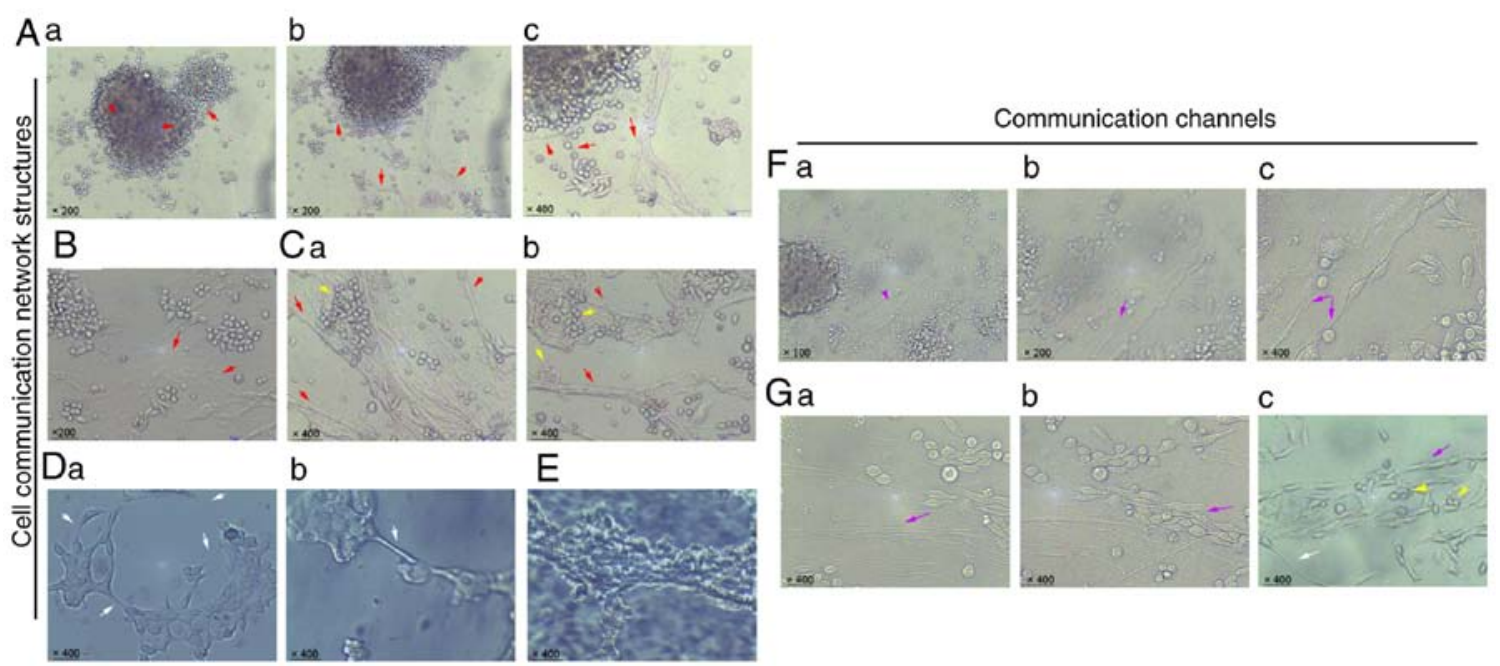

Figure 2. Networks of cellular communication structures are distributed in vitro. (Aa-c) Microtubule-like structures were distributed between mammospheres and mammospheres, mammospheres and cells (red arrows indicate microtubules; magnification: Aa and b, x200; Ac, x400). (B and C) Networks of microtubules differentiating and evolving (red arrows indicate microtubules; yellow arrows indicate connection between cancer cells and cell cluster; magnification: B, x200; Ca and b, x400). (Da and b) Nanotube-like structures among cell-to-cell and mammosphere-to-mammosphere links (white arrows; magnification, x400). (E) Cord-like connective structure of cancer cells (magnification, x400). (Fa-c) Similar channel network formation between mammospheres and cells (purple arrows indicate the deformed connective cells; magnification: Fa, x100; Fb, x200; Fc, x400). (Ga-c) Similar channel network formation with pipe-like vasculogenic mimicry (purple arrows indicate the deformed elongated cells, yellow arrows indicate the free round cells and the white arrow indicates the nanotube-like structure; magnification, $\mathrm{x} 400$ ).

indicated that the percentage of $\mathrm{CD} 44^{+} / \mathrm{CD} 24^{+}$cells was significantly increased in MDA-MB-231 $(22.65 \pm 5.59 \%)$ and primary MDA-MB-231 mammospheres $(35.43 \pm 3.03 \%)$ compared with the parental MDA-MB-231 cells $(1.81 \pm 1.16 \%$; Fig. 3; $\mathrm{P}<0.01$ and $\mathrm{P}<0.001)(30,31)$. However, the percentage of $\mathrm{CD}^{2} 4^{+} / \mathrm{CD} 24^{-}$cells was decreased in both MDA-MB-231 $(75.89 \pm 6.34 \%)$ and primary MDA-MB-231 mammospheres (53.48 $\pm 4.99 \%)$ compared with the parental cells $(97.25 \pm 1.74 \%$; Fig. 3; $\mathrm{P}<0.01$ and $\mathrm{P}<0.001)$. Conversely, the percentage of $\mathrm{CD} 44^{+} / \mathrm{CD} 24^{-}$cells was significantly increased in MCF-7 mammospheres $(7.26 \pm 2.36 \%)$ and primary MCF-7 mammospheres $(22.42 \pm 3.52 \%)$ compared with the parental MCF-7 cells $(0.31 \pm 0.32 \% ; \mathrm{P}<0.05$ and $\mathrm{P}<0.001)$. Similarly, the percentage of $\mathrm{CD} 44^{+} / \mathrm{CD} 24^{+}$cells was significantly increased in both MCF-7 mammospheres $(88.49 \pm 4.92 \%)$ and primary MCF-7 mammospheres $(76.33 \pm 4.12 \%)$ compared with the parental MCF-7 cells $(0.31 \pm 0.32 \%$; Fig. 3 ; $\mathrm{P}<0.001$ and $\mathrm{P}<0.001)$. In conclusion, the percentage of $\mathrm{CD} 44^{+} / \mathrm{CD} 24^{+}$ cells was significantly increased in the MDA-MB-231/MCF-7 mammospheres and primary mammospheres, compared with in their parental cells. The MDA-MB-231 group had a higher proportion of $\mathrm{CD} 44^{+} / \mathrm{CD} 24-$ cells than the MCF-7 group.

Cell cycle arrest in mammospheres. Cell cycle progression and the distribution of cells at different phases of the cell cycle are shown in Fig. 4. When compared with the parental MDA-MB-231 cells, a higher percentage of $\mathrm{G}_{0} / \mathrm{G}_{1}$ and $\mathrm{G}_{2} / \mathrm{M}$ phase cells was distributed in MDA-MB-231 and primary mammospheres (Fig. 4; $\mathrm{P}<0.001$ and $\mathrm{P}<0.001$; $\mathrm{P}<0.05$ and $\mathrm{P}<0.01)$. The percentage of $\mathrm{S}$ phase cells in the parental MDA-MB-231 group was higher than that in the MDA-MB-231 and primary mammospheres (Fig. 4; $\mathrm{P}<0.001$ and $\mathrm{P}<0.001)$. The cell cycle distribution trend of the MCF-7 group was similar to that of the MDA-MB-231 group. Analysis of cell cycle progression indicated that mammospheres may carry more dormant cells compared with the parental cells, and thus may exhibit a more flexible space for proliferation and differentiation.

High expression of stemness-, invasiveness- and angiogenesis-associated genes in mammospheres. Gene expression levels in mammospheres were compared with those in parental cells using quantitative PCR. The results demonstrated that CD44, c-Myc and SRY-box 2 genes, which are associated with stemness, were all significantly increased in primary MDA-MB-231 and primary MCF-7 mammospheres compared with the parental cells (Fig. 5A-C). Nanog homeobox and POU class 5 homeobox 1, which are genes associated with reproduction and stemness (32), were also significantly increased in primary MDA-MB-231 and primary MCF-7 mammospheres (Fig. 5D and $\mathrm{E}, \mathrm{P}<0.01$ ). MMP1, which is a gene associated with invasiveness, and VEGF, which is associated with angiogenesis (33), were also significantly increased in primary MDA-MB-231 and primary MCF-7 mammospheres (Fig. 5F and $\mathrm{G})$. Combined, these results indicated that the aforementioned genes have been significantly enriched and expressed in primary mammospheres compared with in the parental cells.

Collective invasion in mammospheres through cellular communication. To investigate whether cellular communication was directly involved in collective invasion, a series of invasion assays were performed in vitro. The results demonstrated that primary MDA-MB-231 mammospheres started collective invasion once the mammospheres gathered and joined into larger mammospheres (Fig. 6A). Subsequently, the front cells of the mammospheres broke the matrix gel and invaded into the bottom of the culture bottles (Fig. 6B and C). Along with the traction of cell cords and microtubule-like structures, mammospheres and cells gradually invaded in an almost completely collective manner (Fig. 6D and E). Cellular cable-like connections between 

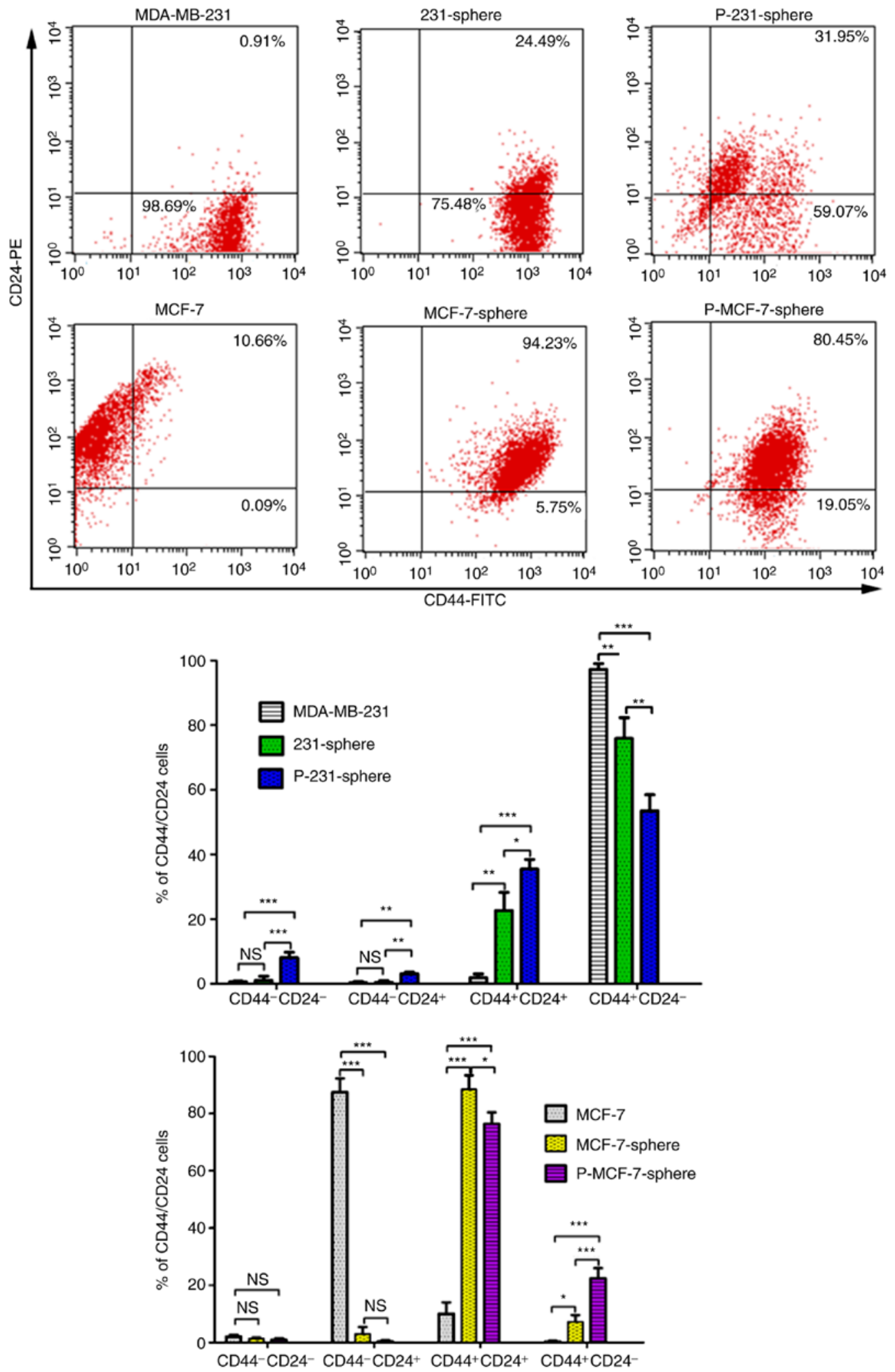

Figure 3. Expression profiles of CD44 and CD24 in parental and mammosphere cell groups. All samples were tested using flow cytometry. Cell samples were double stained with anti-CD44-FITC and anti-CD24-PE. FITC-IgG and PE-IgG were used as isotype controls for gating. Representative plots are presented. The percentage of CD44 and CD24 among the groups was compared using one-way analysis of variance followed by Tukey's test and the data are expressed as the means \pm standard deviation. ${ }^{*} \mathrm{P}<0.05,{ }^{* *} \mathrm{P}<0.01$ and ${ }^{* * *} \mathrm{P}<0.001$. CD, cluster of differentiation; FITC, fluorescein isothiocyanate; PE, phycoerythrin.

cell clusters were also revealed to participate in the collective invasion process (Fig. 6E). Subsequently, non-trypsin-treated mammospheres were analyzed using the transwell migration assay. The results revealed that mammospheres migrated collectively by following and surrounding long, strip-shaped connection cells (Fig. 6F).

Since VEGF was considered to serve an important role in collective cancer cell migration (8), and low dose of 

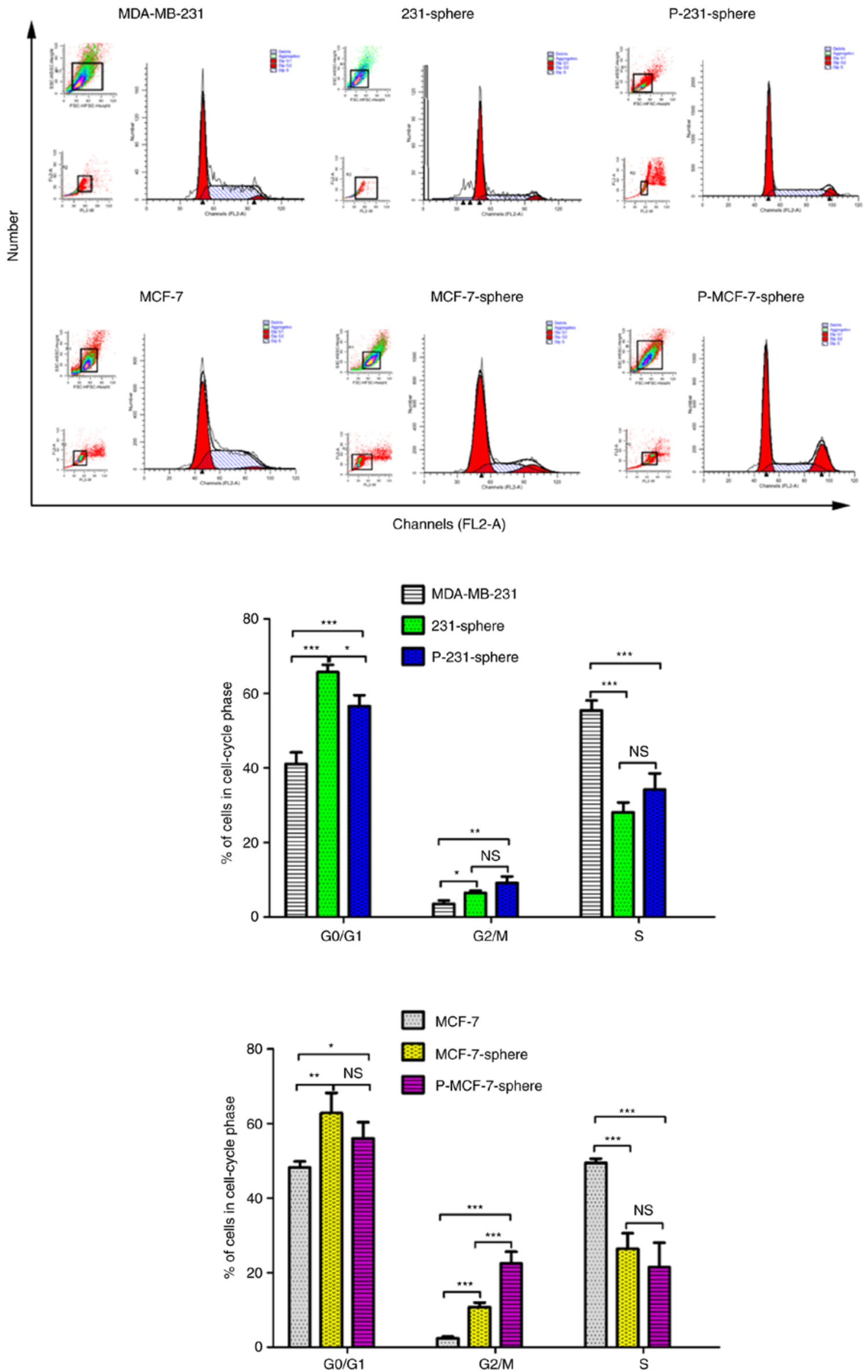

Figure 4. Cell cycle comparison between parental and mammosphere cell groups. Data were compared using one-way analysis of variance followed by Tukey's test and are expressed as the means \pm standard deviation. Cell samples were stained with propidium iodide and cell cycle analysis was conducted using flow cytometry. ${ }^{*} \mathrm{P}<0.05,{ }^{* *} \mathrm{P}<0.01$ and ${ }^{* * *} \mathrm{P}<0.001$. 
A

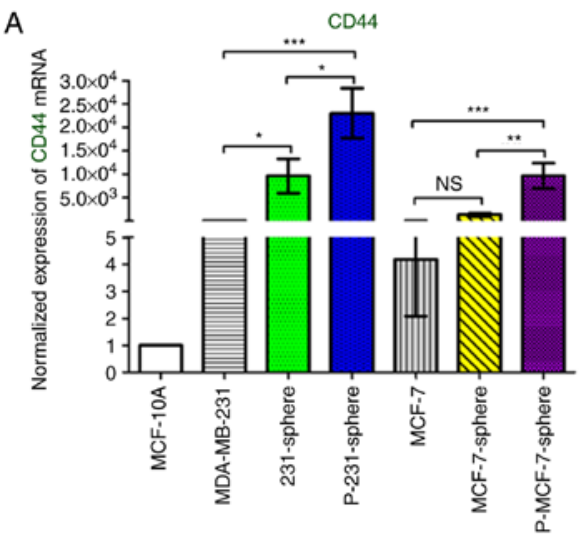

C

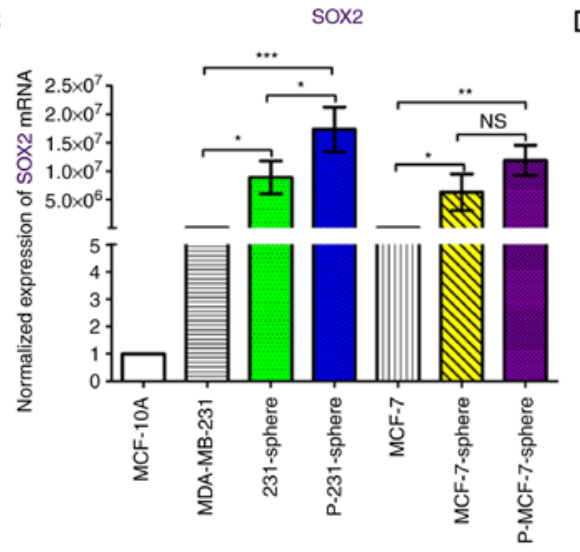

E

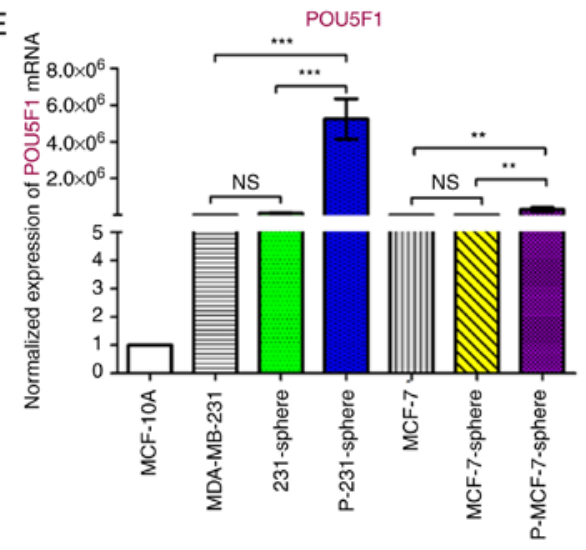

B

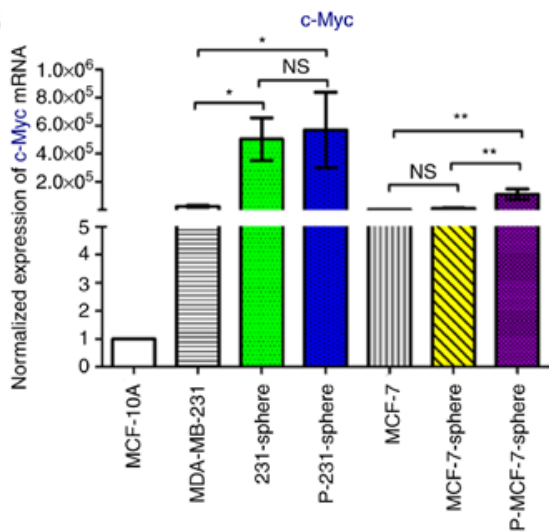

D
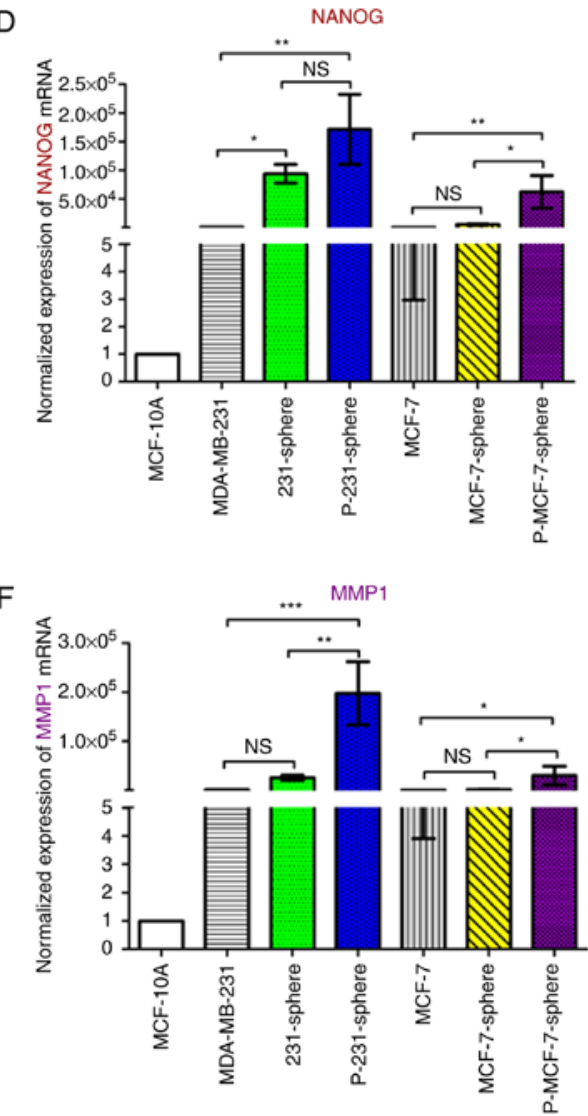

G

VEGF

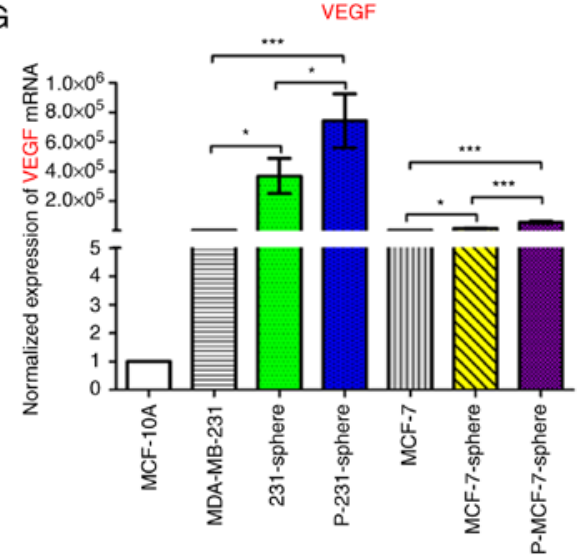

Figure 5. Expression levels of stemness-, invasiveness- and angiogenesis-associated genes are increased in mammospheres. (A-G) Normalized gene expression was compared to MCF-10A for standardization. All PCR data were detected using the Bio-Rad Connect Real-Time PCR platform. Normalized Cq values were converted to relative $\log _{10}$ or $\log _{2}$ expression values, and the gene expression levels were calculated using the $2^{-\Delta \Delta C q}$ method. Relative gene expression data were compared using one-way analysis of variance, followed by Tukey's test, and are expressed as the means \pm standard deviation. ${ }^{*} \mathrm{P}<0.05,{ }^{* * *} \mathrm{P}<0.01$ and ${ }^{* * * *} \mathrm{P}<0.001$. CD44, cluster of differentiation 44; Cq, quantification cycle; MMP1, matrix metalloproteinase 1; NANOG, Nanog homeobox; PCR, polymerase chain reaction; POU5F1, POU class 5 homeobox 1; SOX2, SRY-box 2; VEGF, vascular endothelial growth factor. 


\section{A}

B

C

D

E
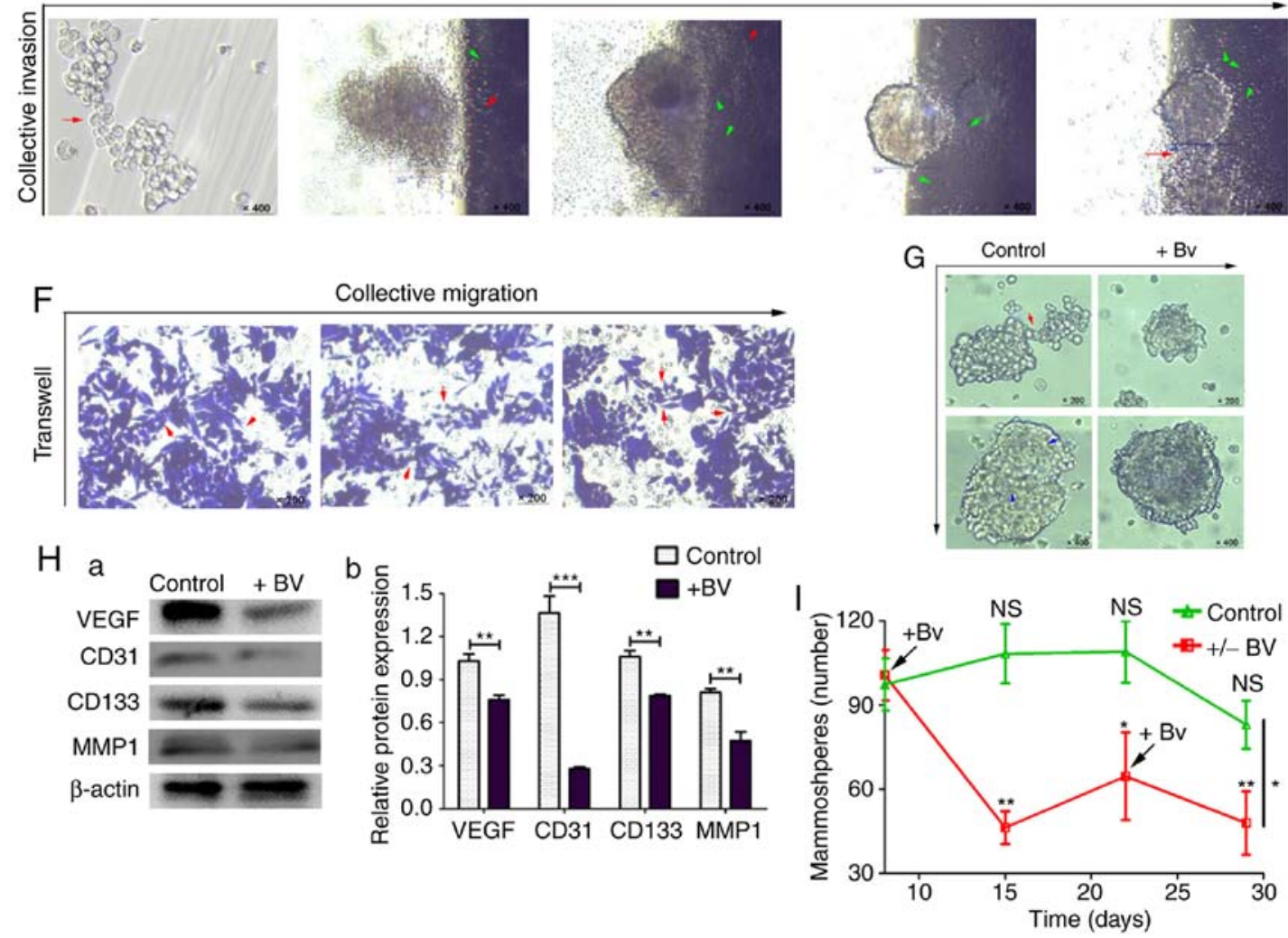

Figure 6. Mammospheres collectively migrate, invade and grow through cellular communication and angiogenesis. (A) Invasive adherent growth (red arrow indicates the connected cell cluster; magnification, x400). (B-E) Collective invasion of mammospheres (green arrows indicate the microtubule-like structures; red arrows indicate the long strip cell transfer connections; magnification, $\mathrm{x} 400$ ). (F) Collective migration, as observed using the transwell assay on non-trypsin-treated cells (red arrows indicate the connecting cell bundles in migration; magnification, $\mathrm{x} 200)$. (G) Bevacizumab (5 $\mu \mathrm{g} / \mathrm{ml})$ reduced mammosphere communication links and weakened mammosphere light transmission (red arrow indicates the connecting cell bundle; magnification, $\mathrm{x} 200$; blue arrows indicate the microtubule-like structures; magnification, $\mathrm{x} 400$ ). (Ha and b) Western blot analysis of the relative protein expression levels of VEGF, CD31, CD133 and MMP1 in each group. Data were compared using the Student's t-test and are expressed as the means \pm standard error of the mean. ${ }^{* *} \mathrm{P}<0.01$ and ${ }^{* * * *} \mathrm{P}<0.001$. (I) Formation and inhibition line of stem-like mammospheres (+Bv represents the addition of $5 \mu \mathrm{g} / \mathrm{ml}$ bevacizumab). Data between the control and $+/-\mathrm{Bv}$ groups were compared using the Student's t-test at day $29,{ }^{*} \mathrm{P}<0.05$; and data within each group were compared using one-way analysis of variance followed by Tukey's test. Day 22 vs. day $8,{ }^{*} \mathrm{P}<0.05$; day 15 and day 29 vs. day $8,{ }^{* *} \mathrm{P}<0.01$. CD, cluster of differentiation; MMP1, matrix metalloproteinase-1; NS, not significant; VEGF, vascular endothelial growth factor.

bevacizumab could target the VEGF-dependent transendothelial migration of cancer cells (34), it was hypothesized that low dose of anti-VEGF intervention could potentially inhibit cellular communication. The results demonstrated that following the addition of bevacizumab $(5 \mu \mathrm{g} / \mathrm{ml})(27)$, after $24 \mathrm{~h}$, the number of peripheral connective cells and microtubule-like structures in the primary MDA-MB-231 mammospheres were clearly decreased (Fig. 6G). In addition, anti-VEGF intervention resulted in reduced activity of mammospheres, with much lower light transmission compared with the control group (Fig. 6G). Western blot analysis revealed that angiogenesis-associated VEGF and CD31, stemness-associated CD133 (4) and invasion-associated MMP1 proteins were significantly decreased following bevacizumab intervention (Fig. 6Ha and b; $\mathrm{P}<0.01$ ).

In order to further study the effects of anti-angiogenic therapy on the formation of mammospheres, stem-like cells were sorted and $\sim 1 \times 10^{3}$ cells were allocated to each group. The results demonstrated that following the addition of bevacizumab, the formation of mammospheres was significantly inhibited (Fig. 6I, Table II; P<0.01). However, during the period ( $\sim 2$ weeks) when no bevacizumab was added, the number of mammospheres formed increased once again. Notably, the number of mammospheres decreased following the second addition of bevacizumab (Fig. 6I). Compared with the control group, mammosphere growth was significantly reduced in the intervention group during the same period (Table II; $\mathrm{P}<0.05$ ). These results indicated that by inhibiting angiogenesis, the formation ability of stem-like mammospheres may be effectively inhibited.

CSC and vascular niche formation promote cancer progression by cellular communication in vivo. In order to further clarify whether cellular communication exists in vivo, tumorigenesis was compared between the MDA-MB-231 mammospheres and parental MDA-MB-231 cells. A minimum of $1 \times 10^{6}$ MDA-MB-231 cells was required to induce tumor formation, whereas $<1 \times 10^{4}$ mammospheres were able to induce tumorigenesis (Fig. 7Aa and b). The results revealed that more tumor nodules, of a larger size, were formed in the mammosphere group, which had more irregular nodular-like protrusions (Fig. 7Aa and b, and Table III). In addition, faster growth and larger tumor volume were observed in the mammosphere group (Fig. 7Aa and b). Notably, tumor angiogenesis 
Table II. Mammosphere formation and inhibition rate.

\begin{tabular}{lcccc}
\hline Sample group & Initial number of CSCs (n) & Time (days) & Number of mammospheres (n) $^{\text {P-value }}$ \\
\hline Control 1 & $1 \times 10^{3}$ & 8 & $97.3 \pm 9.3$ & 0.6779 \\
$(-) \mathrm{Bv}$ & $1 \times 10^{3}$ & & $100.7 \pm 9.0$ & $08.3 \pm 10.6$ \\
Control 2 & $1 \times 10^{3}$ & 15 & $46.3 \pm 5.9$ & $0.0009^{\mathrm{b}}$ \\
$(+) \mathrm{Bv}$ & $1 \times 10^{3}$ & 22 & $109.0 \pm 11.0$ & $0.0159^{\mathrm{c}}$ \\
Control 3 & $1 \times 10^{3}$ & & $83.0 \pm 15.6$ & $0.0128^{\mathrm{c}}$ \\
$(+/-) \mathrm{Bv}$ & $1 \times 10^{3}$ & 29 & $48.0 \pm 11.3$ & \\
Control 4 & $1 \times 10^{3}$ & &
\end{tabular}

${ }^{a} \mathrm{P}$-value was determined using the Student's t-test, control group vs. intervention group; ${ }^{b} \mathrm{P}<0.001,{ }^{\mathrm{c}} \mathrm{P}<0.05$. (-) Bv indicates lack of bevacizumab addition for 1 week. (+) Bv indicates bevacizumab addition after 1 week. (+/-) Bv indicates bevacizumab addition after 1 week, followed by lack of addition for 1 week. $(+/-/+) \mathrm{Bv}$ indicates bevacizumab addition after 1 week, followed by lack of addition for 1 week, and further addition for 1 week.

Table III. Number of subcutaneous tumors and their diameters.

\begin{tabular}{|c|c|c|c|c|}
\hline \multirow[b]{2}{*}{ Mouse number } & \multicolumn{2}{|c|}{ Number of subcutaneous nodules (n) } & \multicolumn{2}{|c|}{ Diameter of each subcutaneous nodule $(\mathrm{cm})$} \\
\hline & MDA-MB-231 & Mammosphere & MDA-MB-231 & Mammosphere \\
\hline 1 & 1 & 1 & 1.55 & 1.63 \\
\hline 2 & 1 & 2 & 1.43 & $1.60,0.15$ \\
\hline 3 & 1 & 2 & 1.40 & $1.54,0.25$ \\
\hline 4 & 1 & 2 & 1.32 & $1.53,0.31$ \\
\hline 5 & 1 & 3 & 1.22 & $1.50,0.22,0.14$ \\
\hline 6 & 1 & 3 & 1.38 & $1.43,0.24,0.15$ \\
\hline 7 & 1 & 3 & 1.11 & $1.38,0.31,0.17$ \\
\hline \multirow[t]{2}{*}{8} & 2 & 3 & 1.06 & $1.32,0.22,0.21$ \\
\hline & & & 0.48 & \\
\hline \multirow[t]{2}{*}{9} & 2 & 3 & 1.01 & $1.27,0.30,0.12$ \\
\hline & & & 0.66 & \\
\hline \multirow[t]{2}{*}{10} & 2 & 4 & 0.93 & $1.16,0.51,0.15,0.11$ \\
\hline & & & 0.72 & \\
\hline P-value & $0.0005^{\mathrm{b}}$ & & $0.0275^{\mathrm{c}}$ & \\
\hline
\end{tabular}

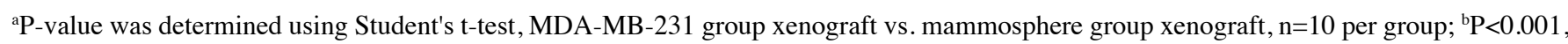
${ }^{\mathrm{c}} \mathrm{P}<0.05$.

was often observed around these nodules in the mammosphere group (Fig. 7Ba and b). Metastatic lung or liver lesions were also observed in the mammosphere group (Fig. 7C). Together, these results indicated that mammospheres may promote xenograft growth and metastasis through irregular nodules and angiogenesis.

H\&E staining indicated that more microtubule-like structures and similar cellular strand connections appeared in the tissues of the mammosphere group compared with those of the parental MDA-MB-231 cell group (Fig. 7D). In addition, immunohistochemistry detected a higher positive expression of VEGF, PCNA and MMP1 in the mammosphere group compared with in the parental MDA-MB-231 cell group
(Fig. 7E and Table IV). Analysis of the stained area revealed that all three proteins were expressed near cancer nests (Fig. 7E). Subsequently, CD31 staining was used to calculate the MVD; the MVD in the mammosphere group was clearly higher than that in the parental MDA-MB-231 group (Fig. 7F; $\mathrm{P}<0.001)$. Immunofluorescence detection demonstrated that a large number of tumor vascular cells gathered around the CSC niches and tubular channels in the mammosphere group (Fig. 7G). CD133 ${ }^{+}$cells were concentrically distributed along the tumor blood vessels and channel structures. In particular, CD133 could be delivered or distributed further along the tissue tubular channels in the mammosphere group (Fig. 7G) (19). These results indicated that CSCs and vascular niches may 


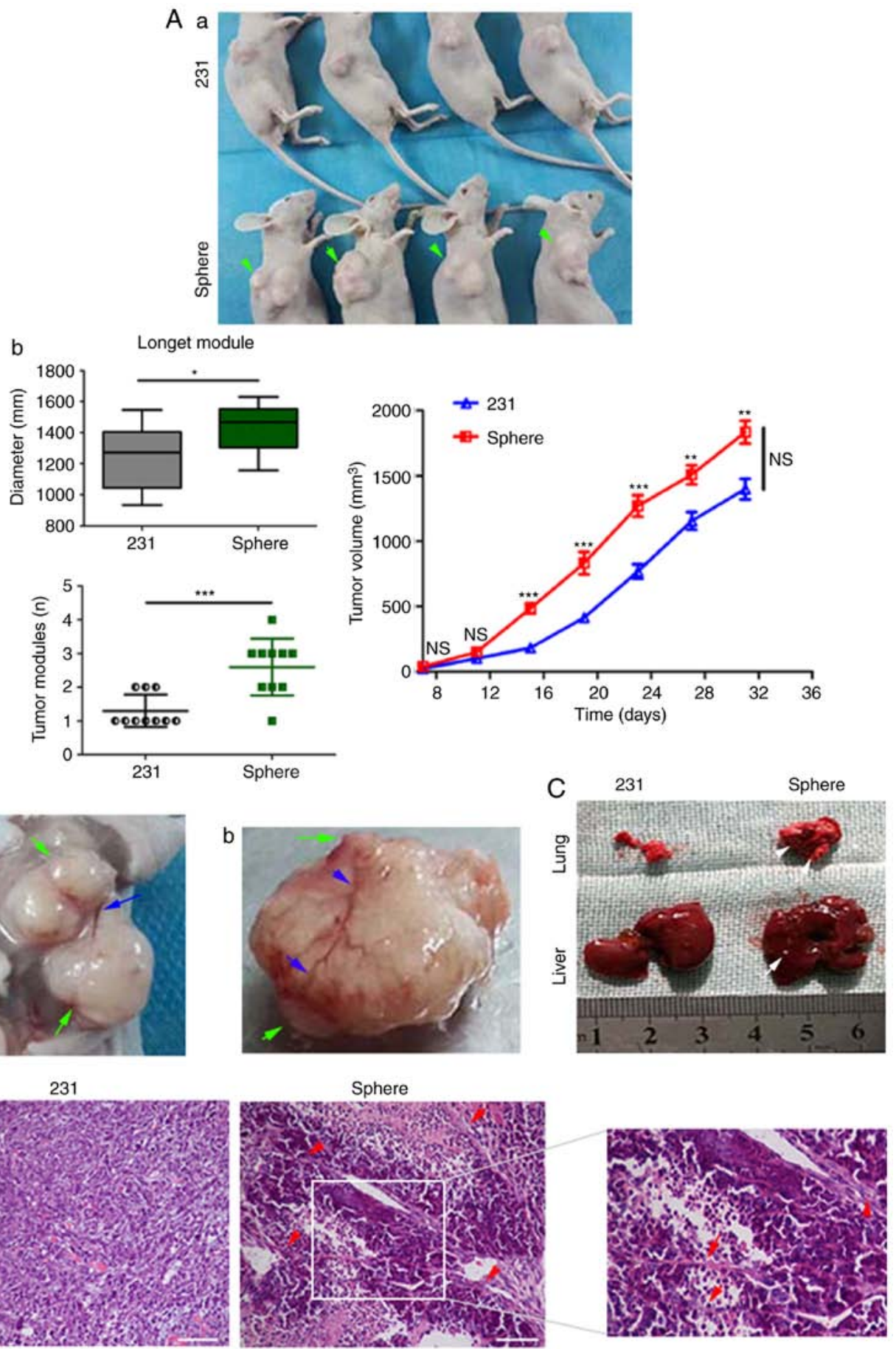

Figure 7. Cellular communication in vivo promotes tumor progression. (Aa and b) Tumor size, volume and growth curve of mice (green arrows indicate multiple fusion or subcutaneous metastatic nodules). Data were compared using Student's t-test and are expressed as the means \pm standard error of the mean ( $\mathrm{n}=10$ /group). ${ }^{*} \mathrm{P}<0.05,{ }^{* * *} \mathrm{P}<0.01$ and ${ }^{* * *} \mathrm{P}<0.001$. (Ba and b) Tumor nodules and protrusions (green arrows) and tumor angiogenesis vessels (blue arrows). (C) Lung and liver metastases (white arrows). (D) Large microtubules and cable-like structures (hematoxylin and eosin staining, red arrows; scale bars, $100 \mu \mathrm{m})$.

be closely associated with angiogenesis and tubular channels, which are widely distributed in these highly metastatic tissues. All these may enhance the communication between CSC niches and cancer cells in vivo.

\section{Discussion}

Cellular communication through synapses and tube structures has recently attracted the attention of researchers (16).
However, reports of such structures during conventional cancer cell culture in vitro are rare (16). Cellular communication structures, such as nanotubes or microtubules, have mainly been reported in developmental biology (16-18). In the present study, such cellular communication structures were observed during mammosphere formation and differentiation in vitro, proving that microtubule-like structural networks may be present in vitro. Notably, although cell protrusion has been reported in tumor growth of human gliomas (20), to the 
E
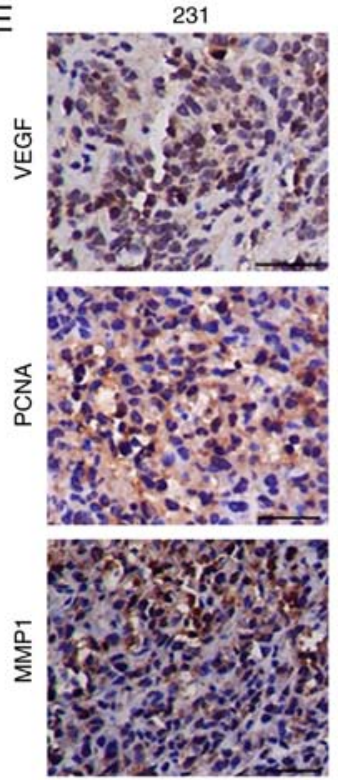

G
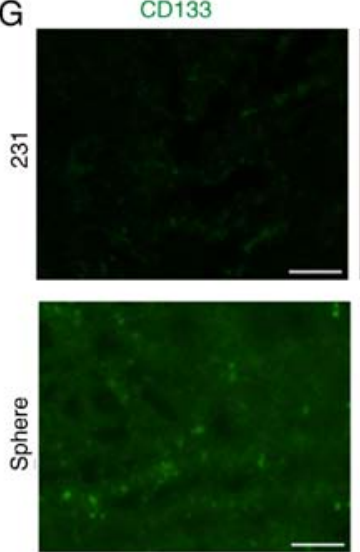

Sphere
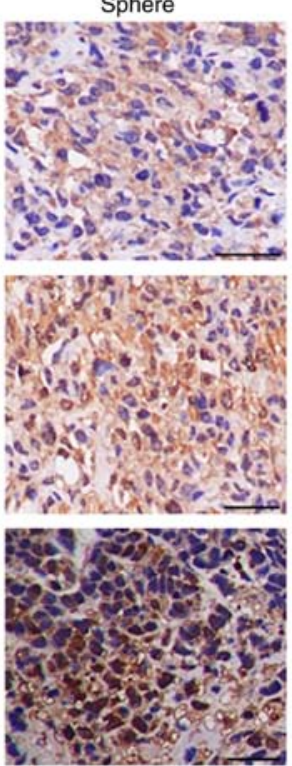

CD31
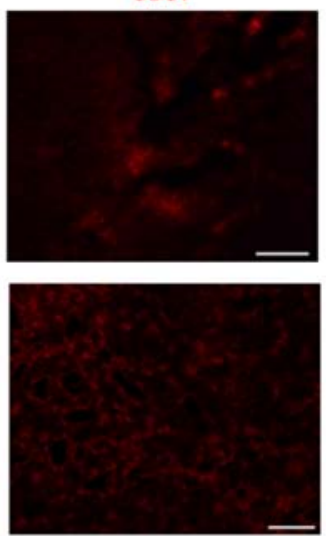

F
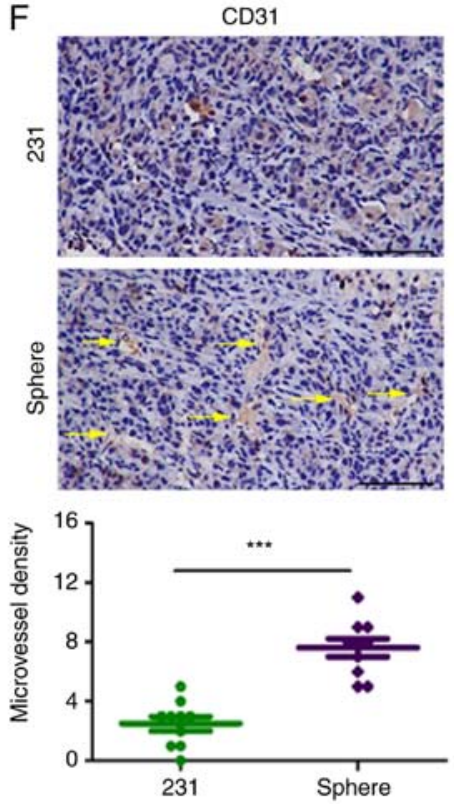

DAPI
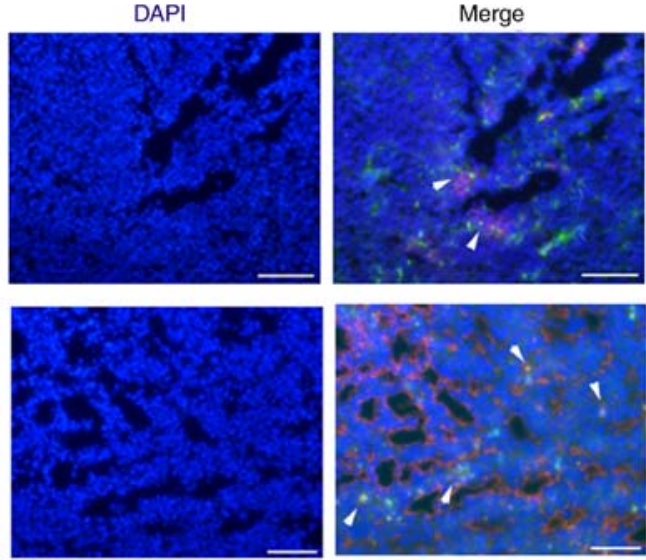

Figure 7. Continued. Cellular communication in vivo promotes tumor progression. (E) Immunohistochemistry of tumor cells in both groups using anti-VEGF, -PCNA and -MMP1 ( $\mathrm{n}=10$ /group; scale bars, $50 \mu \mathrm{m}$ ). (F) Tumor MVD was calculated using CD31 to mark vascular endothelial cells (yellow arrows, immunohistochemistry; scale bars, $100 \mu \mathrm{m})$. Data were compared using Student's t-test and are expressed as the means \pm standard error of the mean. ${ }^{* * *} \mathrm{P}<0.001$. (G) Immunofluorescence staining of tumor sections showing the quantity of CSCs (CD133+, green fluorescence) and tumor angiogenic cells $\left(\mathrm{CD} 31^{+}\right.$, red fluorescence; scale bars, $\left.100 \mu \mathrm{m}\right)$. Nuclei were stained with DAPI. White arrows indicate CD133 ${ }^{+}$cells. CD, cluster of differentiation; DAPI, 4',6-diamidino-2-phenylindole; MMP1, matrix metalloproteinase-1; PCNA, proliferating cell nuclear antigen; VEGF, vascular endothelial growth factor.

best of our knowledge, the present study is the first to detect similar cell protrusions dynamically forming on mammospheres. An increasing number of studies have reported that antenna-like cell protrusions participate in cellular information exchange $(20,29,35)$. Herein, it was determined that these cell protrusions promoted not only cell fusion, but also cellular communication. Notably, it was further observed that some microtubule-like structures and contacts joined in these mammosphere-to-mammosphere communications. Since low doses of serum-containing medium can promote CSC differentiation and facilitate its observation $(36,37)$, large microtubule-like structures outside or inside mammospheres were observed when $1 \%$ serum-containing medium was added. Further culture revealed that various networks of microtubules were differentiated, with some presenting as a net of vascular and fibrous morphology. In addition, nanotube-like structures on membranes formed part of cellular networks. Based on these networks of microtubule-like structures, cell-to-cell, mammosphere-to-mammosphere and mammosphere-to-cell connection may occur, potentially allowing information to be exchanged.

The present study aimed to determine how cellular communication is reflected in mammospheres. Previous studies have revealed that mammospheres are groups of multi-differentiated cells $(1,10)$; therefore, it was hypothesized that there may be a common characteristic between stemness and differentiation that leads to the continuous exchange of information in mammospheres. In the present study, CD $44^{+} / \mathrm{CD} 24^{+}$cells were significantly increased in all mammosphere groups; however, the proportion of $\mathrm{CD} 44^{+} / \mathrm{CD} 24^{-}$cells varied according to different parental cell lines. Since the early stages of high proliferation, invasion and heterogeneous differentiation are partly attributed to $\mathrm{CD} 24^{+}$cells in mammary tumors $(30,38,39)$, and stemness characteristics are mainly attributed to CD44 cells $(2,31,40)$, the co-expression of CD44 and CD24 may result in high levels of stemness and differentiation in mammospheres. The cell cycle results indicated that mammospheres exhibited a more flexible space for division. Genes associated 
Table IV. Immunohistochemical analysis of positive expression levels of VEGF, PCNA and MMP1 in two mouse group samples.

\begin{tabular}{|c|c|c|c|c|c|c|c|}
\hline \multirow[b]{2}{*}{ Protein } & \multirow[b]{2}{*}{$\mathrm{n}$} & \multicolumn{4}{|c|}{ Expression } & \multirow[b]{2}{*}{ Proportion of $+++(\%)$} & \multirow[b]{2}{*}{ P-value } \\
\hline & & - & + & ++ & +++ & & \\
\hline VEGF & & & & & & & $0.020^{\mathrm{a}, \mathrm{b}}$ \\
\hline MDA-MB-231 & 10 & 2 & 3 & 4 & 1 & 10.0 & \\
\hline Mammosphere & 10 & 1 & 1 & 1 & 7 & 70.0 & \\
\hline PCNA & & & & & & & $0.007^{\mathrm{c}, \mathrm{d}}$ \\
\hline MDA-MB-231 & 10 & 1 & 3 & 4 & 2 & 20.0 & \\
\hline Mammosphere & 10 & 0 & 2 & 0 & 8 & 80.0 & \\
\hline MMP1 & & & & & & & $0.033^{\mathrm{a}, \mathrm{b}}$ \\
\hline MDA-MB-231 & 10 & 2 & 4 & 4 & 0 & 0.0 & \\
\hline Mammosphere & 10 & 1 & 3 & 1 & 5 & 50.0 & \\
\hline
\end{tabular}

${ }^{\mathrm{a}} \mathrm{P}<0.05$; ${ }^{\mathrm{b}} \mathrm{P}$-value was determined using the Fisher's exact test; ${ }^{\mathrm{c}} \mathrm{P}<0.01$; ${ }^{\mathrm{d}} \mathrm{P}$-value was determined using the $\chi^{2}$ test. MMP1, matrix metalloproteinase 1; PCNA, proliferating cell nuclear antigen; VEGF, vascular endothelial growth factor.

with stemness, invasiveness and angiogenesis were all highly expressed in mammospheres. The results from the breast cancer cell line analysis revealed that mammospheres and primary mammospheres exhibited a highly invasive collective cell state, in which stemness and multi-differentiation factors were detected (41). It may be hypothesized that the phenotypic alteration of cells gives rise to an equilibrium state in mammospheres, requiring continuous information exchange between cells.

Studies regarding CSCs and cell clusters have made great progress in determining the mechanism of collective tumor metastasis $(7,8,42)$. In the present study, it was confirmed that cellular communication may participate in this process. During mammosphere migration and invasion, the leader cells, follower cells and mammospheres moved collectively (8). The results of an invasion analysis demonstrated that microtubule-like structures and cellular cord-like connections were constantly accompanying each other and induced interconnection of cell clusters. Cellular information appeared to constantly be exchanged through this collective movement $(8,18)$. Konen et al predicted that there is some cooperation between leader and follower cells in cell cultures during their movement (8).

Since it has been reported that collective cancer movement is mainly associated with VEGF and fibroblast growth factor $(8,43)$, it was suggested that anti-VEGF or anti-angiogenic therapy could inhibit communication. Morphologically, mammosphere growth was significantly inhibited, and the associated cell connections and microtubule-like structures were markedly reduced in response to anti-VEGF. Protein detection revealed that anti-VEGF intervention not only inhibited VEGF and CD31, but also significantly reduced the expression of proteins associated with stemness and invasiveness. The results of the growth and inhibition line analysis demonstrated that anti-VEGF intervention could effectively inhibit the formation and growth of stem-like mammospheres. Through comprehensive analysis, it was hypothesized that the cascade response to anti-VEGF therapy might effectively inhibit the multilineage differentiation of
CSCs. VEGF has been reported to serve an important role in information exchange during cell differentiation, including the differentiation of functional endothelium (44), stem cell remodeling (45), and to have extensive effects on tumor microvasculature (46). However, the therapeutic effects of anti-VEGF treatment can be reduced when the addition of the drug is interrupted $(47,48)$. It was hypothesized that, due to the persistence of cellular communication, the inhibition of stem-like mammosphere growth and invasion may be one of the reasons for the need for continuous intervention.

In vivo, xenografts from mammospheres promoted tumor growth and metastasis through the development of fusion nodules and angiogenesis. Staining confirmed that the number of microtubule-like channels in mammosphere tissues was increased, and the channels were much longer and messier than those in the parental cell tissues. Immunohistochemical analysis indicated that VEGF, PCNA and MMP1 not only exhibited higher expression in the mammosphere group tissues, but also around cancer nests. MVD was significantly increased and was widely distributed in the mammosphere tissue group, which indicated a large number of microvascular channels within these tissues. This was more apparent in CSCs and vascular niches. As previous studies have reported that CSCs or vascular niches may be the base for metastasis and network-like information export and exchange $(15,49,50)$, it was hypothesized that cellular communication would be more strongly observed near these niches in vivo. However, the transmission of information to the distant areas of the tissues may still need to occur through microtubule-like channels, cell-associated cords or tumor angiogenesis. As previously shown, $\mathrm{CD}_{133^{+}}$was not only distributed along the CD $31^{+}$ cell strip, but could also be delivered further along the tissue tubular channels (19).

In conclusion, the results of the present study indicated that cellular communication was not only widely present in the growth and differentiation processes of mammospheres in vitro, but was also reflected in vivo. The collective characteristics of stemness and differentiation in mammospheres 
contributed to the continuous exchange of information. Furthermore, anti-angiogenic treatment may be an efficient method of blocking cellular communication; however, more specific mechanisms need to be explored.

\section{Acknowledgements}

Not applicable.

\section{Funding}

The present study was supported by grants from the National Natural Science Foundation of China (grant no. 81272898).

\section{Availability of data and materials}

The datasets used and/or analyzed during the current study are available from the corresponding author on reasonable request.

\section{Authors' contributions}

SH, XZ and LZ conceived and designed the study. SH, NY, GW, FW and LF performed the experiments. SH wrote the manuscript. MLu, MLi and AL edited the manuscript and were also involved in the conception of the study. All authors read and approved the manuscript, and agree to be accountable for all aspects of the research, ensuring that the accuracy or integrity of any part of the work are appropriately investigated and resolved.

\section{Ethics approval and consent to participate}

Mouse care and usage were approved by the Ethics Committee of the School of Medicine of Xi'an Jiaotong University (approval no. 0108; Xi'an, China).

\section{Patient consent for publication}

Not applicable.

\section{Competing interests}

The authors declare that they have no competing interests.

\section{References}

1. Adorno-Cruz V, Kibria G, Liu X, Doherty M, Junk DJ, Guan D, Hubert C, Venere M, Mulkearns-Hubert E, Sinyuk M, et al: Cancer stem cells: Targeting the roots of cancer, seeds of metastasis, and sources of therapy resistance. Cancer Res 75: 924-929, 2015.

2. Al-Hajj M, Wicha MS, Benito-Hernandez A, Morrison SJ and Clarke MF: Prospective identification of tumorigenic breast cancer cells. Proc Natl Acad Sci USA 100: 3983-3988, 2003.

3. Ginestier C, Hur MH, Charafe-Jauffret E, Monville F, Dutcher J, Brown M, Jacquemier J, Viens P, Kleer CG, Liu S, et al: ALDH1 is a marker of normal and malignant human mammary stem cells and a predictor of poor clinical outcome. Cell Stem Cell 1: 555-567, 2007.

4. Liu TJ, Sun BC, Zhao XL, Zhao XM, Sun T, Gu Q, Yao Z, Dong XY, Zhao N and Liu N: CD133 ${ }^{+}$cells with cancer stem cell characteristics associates with vasculogenic mimicry in triple-negative breast cancer. Oncogene 32: 544-553, 2013.
5. Martelotto LG, Ng CK, Piscuoglio S, Weigelt B and Reis-Filho JS: Breast cancer intra-tumor heterogeneity. Breast Cancer Res 16: 210, 2014.

6. Prasetyanti PR and Medema JP: Intra-tumor heterogeneity from a cancer stem cell perspective. Mol Cancer 16: 41, 2017.

7. Cheung KJ, Padmanaban V, Silvestri V, Schipper K, Cohen JD, Fairchild AN, Gorin MA, Verdone JE, Pienta KJ, Bader JS and Ewald AJ: Polyclonal breast cancer metastases arise from collective dissemination of keratin 14-expressing tumor cell clusters. Proc Natl Acad Sci USA 113: E854-E863, 2016.

8. Konen J, Summerbell E, Dwivedi B, Galior K, Hou Y, Rusnak L, Chen A, Saltz J, Zhou W, Boise LH, et al: Image-guided genomics of phenotypically heterogeneous populations reveals vascular signalling during symbiotic collective cancer invasion. Nat Commun 8: 15078, 2017.

9. Santoro A, Vlachou T, Carminati M, Pelicci PG and Mapelli M: Molecular mechanisms of asymmetric divisions in mammary stem cells. EMBO Rep 17: 1700-1720, 2016.

10. van Niekerk G, Davids LM, Hattingh SM and Engelbrecht AM: Cancer stem cells: A product of clonal evolution? Int J Cancer 140: 993-999, 2017.

11. Tang S, Xiang T, Huang S, Zhou J, Wang Z, Xie R, Long H and Zhu B: Ovarian cancer stem-like cells differentiate into endothelial cells and participate in tumor angiogenesis through autocrine CCL5 signaling. Cancer Lett 376: 137-147, 2016.

12. Katajisto P, Döhla J, Chaffer CL, Pentinmikko N, Marjanovic N, Iqbal S, Zoncu R, Chen W, Weinberg RA and Sabatini DM: Stem cells. Asymmetric apportioning of aged mitochondria between daughter cells is required for stemness. Science 348: 340-343, 2015 .

13. Serres E, Debarbieux F, Stanchi F, Maggiorella L, Grall D, Turchi L, Burel-Vandenbos F, Figarella-Branger D, Virolle T, Rougon $\mathrm{G}$ and Van Obberghen-Schilling E: Fibronectin expression in glioblastomas promotes cell cohesion, collective invasion of basement membrane in vitro and orthotopic tumor growth in mice. Oncogene 33: 3451-3462, 2014.

14. Korkaya H, Liu S and Wicha MS: Breast cancer stem cells, cytokine networks, and the tumor microenvironment. J Clin Invest 121: 3804-3809, 2011.

15. Ping YF, Zhang X and Bian XW: Cancer stem cells and their vascular niche: Do they benefit from each other? Cancer Lett 380: 561-567, 2016.

16. Baker M: How the Internet of cells has biologists buzzing. Nature 549: 322-324, 2017.

17. Kornberg TB and Gilboa L: Developmental biology: Nanotubes in the niche. Nature 523: 292-293, 2015.

18. Gerdes HH and Carvalho RN: Intercellular transfer mediated by tunneling nanotubes. Curr Opin Cell Biol 20: 470-475, 2008.

19. Reichert D, Scheinpflug J, Karbanová J, Freund D, Bornhäuser M and Corbeil D: Tunneling nanotubes mediate the transfer of stem cell marker CD133 between hematopoietic progenitor cells. Exp Hematol 44: 1092-1112 e1092, 2016.

20. Osswald M, Jung E, Sahm F, Solecki G, Venkataramani V, Blaes J, Weil S, Horstmann H, Wiestler B, Syed M, et al: Brain tumour cells interconnect to a functional and resistant network. Nature 528: 93-98, 2015.

21. Osswald M, Solecki G, Wick W and Winkler F: A malignant cellular network in gliomas: Potential clinical implications. Neuro Oncol 18: 479-485, 2016.

22. Patheja P and Sahu K: Macrophage conditioned medium induced cellular network formation in MCF-7 cells through enhanced tunneling nanotube formation and tunneling nanotube mediated release of viable cytoplasmic fragments. Exp Cell Res 355: 182-193, 2017.

23. Thayanithy V, Dickson EL, Steer C, Subramanian S and Lou E: Tumor-stromal cross talk: Direct cell-to-cell transfer of oncogenic microRNAs via tunneling nanotubes. Transl Res 164: 359-365, 2014.

24. Dontu G, Abdallah WM, Foley JM, Jackson KW, Clarke MF, Kawamura MJ and Wicha MS: In vitro propagation and transcriptional profiling of human mammary stem/progenitor cells. Genes Dev 17: 1253-1270, 2003.

25. Peleg R, Romzova M, Kogan-Zviagin, Apte RN and Priel E: Modification of topoisomerases in mammospheres derived from breast cancer cell line: Clinical implications for combined treatments with tyrosine kinase inhibitors. BMC Cancer 14: 910, 2014.

26. Livak KJ and Schmittgen TD: Analysis of relative gene expression data using real-time quantitative PCR and the 2(-Delta Delta C(T)) method. Methods 25: 402-408, 2001. 
27. Takahashi H, Nomura Y, Nishida J, Fujino Y, Yanagi Y and Kawashima H: Vascular endothelial growth factor (VEGF) concentration is underestimated by enzyme-linked immunosorbent assay in the presence of anti-VEGF drugs. Invest Ophthalmol Vis Sci 57: 462-466, 2016.

28. Weidner N, Semple JP, Welch WR and Folkman J: Tumor angiogenesis and metastasis-correlation in invasive breast carcinoma. N Engl J Med 324: 1-8, 1991.

29. Ramirez-Weber FA and Kornberg TB: Cytonemes: Cellular processes that project to the principal signaling center in Drosophila imaginal discs. Cell 97: 599-607, 1999.

30. Rostoker R, Abelson S, Genkin I, Ben-Shmuel S, Sachidanandam R, Scheinman EJ, Bitton-Worms K, Orr ZS, Caspi A, Tzukerman M and LeRoith D: CD24(+) cells fuel rapid tumor growth and display high metastatic capacity. Breast Cancer Res 17: 78, 2015.

31. Li W, Ma H, Zhang J, Zhu L, Wang $\mathrm{C}$ and Yang Y: Unraveling the roles of CD44/CD24 and ALDH1 as cancer stem cell markers in tumorigenesis and metastasis. Sci Rep 7: 13856, 2017.

32. Wang Z, Oron E, Nelson B, Razis S and Ivanova N: Distinct lineage specification roles for NANOG, OCT4, and SOX2 in human embryonic stem cells. Cell Stem Cell 10: 440-454, 2012.

33. Ebrahem Q, Chaurasia SS, Vasanji A, Qi JH, Klenotic PA, Cutler A, Asosingh K, Erzurum S and Anand-Apte B: Cross-talk between vascular endothelial growth factor and matrix metalloproteinases in the induction of neovascularization in vivo. Am J Pathol 176: 496-503, 2010.

34. Prager GW, Lackner EM, Krauth MT, Unseld M, Poettler M, Laffer S, Cerny-Reiterer S, Lamm W, Kornek GV, Binder BR, et al: Targeting of VEGF-dependent transendothelial migration of cancer cells by bevacizumab. Mol Oncol 4: 150-160, 2010.

35. Rustom A, Saffrich R, Markovic I, Walther P and Gerdes HH: Nanotubular highways for intercellular organelle transport. Science 303: 1007-1010, 2004

36. Hong X, Chedid K and Kalkanis SN: Glioblastoma cell line-derived spheres in serumcontaining medium versus serum-free medium: A comparison of cancer stem cell properties. Int J Oncol 41: 1693-1700, 2012.

37. deCarvalho AC, Nelson K, Lemke N, Lehman NL, Arbab AS, Kalkanis S and Mikkelsen T: Gliosarcoma stem cells undergo glial and mesenchymal differentiation in vivo. Stem Cells 28: $181-190,2010$

38. Hosonaga M, Arima Y, Sugihara E, Kohno N and Saya H: Expression of CD24 is associated with HER2 expression and supports HER2-Akt signaling in HER2-positive breast cancer cells. Cancer Sci 105: 779-787, 2014

39. Jaggupilli A and Elkord E: Significance of CD44 and CD24 as cancer stem cell markers: An enduring ambiguity. Clin Dev Immunol 2012: 708036, 2012.
40. Camerlingo R, Ferraro GA, De Francesco F, Romano M, Nicoletti G, Di Bonito M, Rinaldo M, D'Andrea F and Pirozzi G: The role of CD44+/CD24-/low biomarker for screening, diagnosis and monitoring of breast cancer. Oncol Rep 31: 1127-1132, 2014.

41. Smart CE, Morrison BJ, Saunus JM, Vargas AC, Keith P, Reid L, Wockner L, Askarian-Amiri M, Sarkar D, Simpson PT, et al: In vitro analysis of breast cancer cell line tumourspheres and primary human breast epithelia mammospheres demonstrates inter- and intrasphere heterogeneity. PLoS One 8: e64388, 2013.

42. Aceto N, Bardia A, Miyamoto DT, Donaldson MC, Wittner BS, Spencer JA, Yu M, Pely A, Engstrom A, Zhu H, et al: Circulating tumor cell clusters are oligoclonal precursors of breast cancer metastasis. Cell 158: 1110-1122, 2014.

43. Karagiannis GS, Poutahidis T, Erdman SE, Kirsch R, Riddell RH and Diamandis EP: Cancer-associated fibroblasts drive the progression of metastasis through both paracrine and mechanical pressure on cancer tissue. Mol Cancer Res 10: 1403-1418, 2012.

44. Nourse MB, Halpin DE, Scatena M, Mortisen DJ, Tulloch NL, Hauch KD, Torok-Storb B, Ratner BD, Pabon L and Murry CE: VEGF induces differentiation of functional endothelium from human embryonic stem cells: Implications for tissue engineering. Arterioscler Thromb Vasc Biol 30: 80-89, 2010.

45. Licht T, Rothe G, Kreisel T, Wolf B, Benny O, Rooney AG, Ffrench-Constant C, Enikolopov G and Keshet E: VEGF preconditioning leads to stem cell remodeling and attenuates age-related decay of adult hippocampal neurogenesis. Proc Natl Acad Sci USA 113: E7828-E7836, 2016.

46. Beck B, Driessens G, Goossens S, Youssef KK, Kuchnio A, Caauwe A, Sotiropoulou PA, Loges S, Lapouge G, Candi A, et al: A vascular niche and a VEGF-Nrp1 loop regulate the initiation and stemness of skin tumours. Nature 478: 399-403, 2011.

47. Xu Y, Li Q, Li XY, Yang QY, Xu WW and Liu GL: Short-term anti-vascular endothelial growth factor treatment elicits vasculogenic mimicry formation of tumors to accelerate metastasis. J Exp Clin Cancer Res 31: 16, 2012.

48. Markowska A, Sajdak S, Markowska J and Huczyński A: Angiogenesis and cancer stem cells: New perspectives on therapy of ovarian cancer. Eur J Med Chem 142: 87-94, 2017.

49. Plaks V, Kong N and Werb Z: The cancer stem cell niche: How essential is the niche in regulating stemness of tumor cells? Cell Stem Cell 16: 225-238, 2015.

50. Hale JS, Li M and Lathia JD: The malignant social network: Cell-cell adhesion and communication in cancer stem cells. Cell Adh Migr 6: 346-355, 2012.

This work is licensed under a Creative Commons Attribution-NonCommercial-NoDerivatives 4.0 International (CC BY-NC-ND 4.0) License. 